\title{
Antioxidant and anticancer effects and bioavailability studies of the flavonoid baicalin and its oxidovanadium(IV) complex
}

\author{
Juan J. Martínez Medina a, ${ }^{\mathrm{a}}$, Luciana G. Naso ${ }^{\mathrm{b}, 1}$, Ana L. Pérez ${ }^{\mathrm{c}}$, Alberto Rizzi ${ }^{\mathrm{c}}$, \\ Evelina G. Ferrer ${ }^{\mathrm{b}}$, Patricia A.M. Williams ${ }^{\mathrm{b}, *}$ \\ a Universidad Nacional del Chaco Austral - Comandante Fernández 755, CP: 3700 Presidencia Roque Sáenz Peña, Chaco, Argentina \\ b CEQUINOR, CONICET/UNLP, Facultad de Ciencias Exactas, Universidad Nacional de La Plata, Bv. 120 N $^{\circ}$ 1465, 1900 La Plata, Argentina \\ c Departamento de Física, Facultad de Bioquímica y Ciencias Biológicas-Universidad Nacional del Litoral, Ciudad Universitaria-Paraje El Pozo, 3000 Santa Fe, Argentina
}

\section{A R T I C L E I N F O}

\section{Article history:}

Received 3 August 2016

Received in revised form 11 October 2016

Accepted 3 November 2016

Available online 05 November 2016

\section{Keywords:}

Oxidovanadium(IV) complex

Baicalin

Antioxidant

Anticancer

BSA binding

\begin{abstract}
A B S T R A C T
Based on the known antioxidant effect of flavonoids, baicalin (baic) found in roots of Scutellaria has been selected. Its coordination complex with the oxidovanadium(IV) cation, $\left.\mathrm{Na}_{4}[\mathrm{VO} \text { (baic) })_{2}\right] \cdot 6 \mathrm{H}_{2} \mathrm{O}\left(\mathrm{V}^{\mathrm{IV}} \mathrm{O}\right.$ (baic)), was synthesized at pH 9 in ethanol and characterized by physicochemical methods. Spectrophotometric studies at pH 9 showed a ligand: metal stoichiometry of 2:1. By vibrational spectroscopy a coordination mode through the cis $5-\mathrm{OH}$ and 6-OH deprotonated groups is inferred. EPR spectroscopy shows an environment of four aryloxide $\left(\mathrm{ArO}^{-}\right)$groups in the equatorial plane of the $\mathrm{V}=0$ moiety, both in solution and in the solid complex. The antioxidant capacity against superoxide and peroxyl radicals of $\mathrm{V}^{\mathrm{IV}} \mathrm{O}$ (baic) resulted greater than for baicalin and correlated with previous results obtained for other Voflavonoid complexes. The coordination mode produces delocalization of the electron density and the stabilization of the radical formed by interaction with external radicals. The complex and the ligand displayed no toxic (Artemia salina test) and no mutagenic (Ames test) effects. The complex improved the ability of the ligand to reduce cell viability of human lung cancer cell lines (A549) generating reactive oxygen species (ROS) in cells, being this effect reversed by pre-incubation of the cells with antioxidants such as vitamins $\mathrm{C}$ and $\mathrm{E}$. The addition of NAC ( $\mathrm{N}$-acetyl-L-cysteine, a sequestering agent of free radicals) suppresses the anticancer effect, confirming the oxidative stress mechanism. The complex interacted with bovine serum albumin (BSA) with stronger binding than baicalin and the mechanisms involved $\mathrm{H}$ bonding and van der Waals interactions.
\end{abstract}

(C) 2016 Elsevier Inc. All rights reserved.

\section{Introduction}

Baicalin (baic, (2S,3S,4S,5R,6S)-6-(5,6-dihydroxy-4-oxo-2-phenylchromen-7-yl)oxy-3,4,5-trihydroxy-tetrahydropyran-2-carboxylic acid) is one of the major bioactive constituents of Scutellariae Radix, widely used in traditional Chinese formulations (Fig. 1). It possesses antiallergic, anti-inflammatory and antioxidant activity [1]. This flavonoid is the glucuronide of baicalein and while this latter compound presents good biological availability, it could not be used for its instability. Baicalin will be the perspective lead compound for its good stability and bioactivity.

It has been reported that the combination of antioxidant compounds such as sulfhydryl containing organic ligands with vanadium improved the antioxidant effect of the ligand and resulted in a new generation of anticancer drugs [2]. Besides, in previous works we have determined

\footnotetext{
* Corresponding author.

E-mail address: williams@quimica.unlp.edu.ar (P.A.M. Williams).

1 These authors have equally contributed to the work.
}

that the complexation of the natural antioxidant compounds, flavonoids, by oxidovanadium(IV) produced an improvement of their antioxidant properties when the interaction occurred through $\mathrm{O}$ atoms of the rings that allowed a delocalization of the electronic density [3 and references therein]. In the present case the coordination of oxidovanadium(IV) cation (VO) through the C-5 and C-6 atoms of baicalin, $\mathrm{V}^{\mathrm{IV}} \mathrm{O}$ (baic), (determined by elemental analysis, thermogravimetric determinations, FTIR and EPR spectroscopies) produced less improvement in the antioxidant properties of the flavonoid than the VOflavonoid complexes in which the coordination occurs through the chelation with $\mathrm{C}=\mathrm{O}(\mathrm{C}-5)$ and a deprotonated hydroxo groups (at $\mathrm{C}-3$ or C-5 atoms of the different flavonoids [4]). The complex displayed better scavenger properties against peroxyl and superoxide radicals than the flavonoid. It also enhanced the anticancer effect of the ligand, on A549 lung cancer cell line, being this action effect more effective at $72 \mathrm{~h}$ of incubation. A stress oxidative mechanism has been determined to be at least one of the reasons of the cell viability inhibition. Baicalin and $\mathrm{V}^{\mathrm{IV}} \mathrm{O}$ (baic) can be stored and removed by bovine serum albumin (BSA). The complex interacted with BSA more strongly than the ligand and the interactions were determined to be through hydrogen bonding 


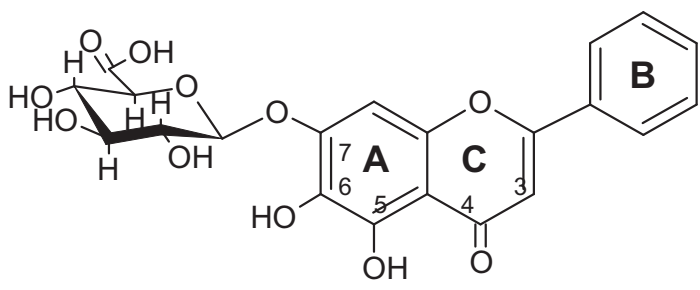

Fig. 1. Schematic representation of Baicalin.

and van der Waals forces. By the acute toxicity studies using Artemia salina [5] it could be shown that only the oxidovanadium(IV) cation produced dead nauplii at the concentrations used for the anticancer determinations but baicalin and $\mathrm{V}^{\mathrm{IV}} \mathrm{O}$ (baic) did not exert toxic effects. Besides, the compounds did not produce genetic damage that leads to gene mutations, determined by the Ames test.

\section{Experimental}

\subsection{Materials and methods}

Baicalin (Xi'an App-Chem Bio(Tech) Co., Ltd) and oxidovanadium(IV) chloride (50\% aqueous solution, Carlo Erba) were used as supplied. Corning or Falcon provided tissue culture materials. Dulbecco's modified Eagle's medium (DMEM) was purchased from Gibco (Gaithersburg, MD, USA), Tryple ${ }^{\mathrm{TM}}$ from Invitrogen (Argentina SRL) and fetal bovine serum (FBS) from Internegocios, Argentina. All other chemicals used were of analytical grade.

Elemental analysis for carbon and hydrogen was performed using a Carlo Erba EA1108 analyzer. Vanadium content was determined by the tungstophosphovanadic method [6]. Sodium contents were performed by flame photometry. A Shimadzu system (model TG-50), working in an oxygen flow of $50 \mathrm{~mL} \cdot \mathrm{min}^{-1}$ and at a heating rate of $10{ }^{\circ} \mathrm{C} \cdot \mathrm{min}^{-1}$ has been used for the thermogravimetric analysis. Sample quantities ranged between 10 and $20 \mathrm{mg}$. UV-vis spectra determinations were recorded with a Hewlett-Packard 8453 diode-array spectrophotometer. The diffuse reflectance spectrum was performed using a Shimadzu UV-300 spectrophotometer, with $\mathrm{MgO}$ as a standard. Infrared spectra were measured with a Bruker IFS 66 FTIR spectrophotometer from 4000 to $400 \mathrm{~cm}^{-1}$ using the $\mathrm{KBr}$ pellet technique. X-band CW-EPR spectra of powdered samples were obtained at room temperature on a Bruker EMX-Plus spectrometer, equipped with a rectangular cavity with $100 \mathrm{kHz}$ field modulation. X band EPR spectra of frozen DMSO solutions were recorded at $120 \mathrm{~K}$. EPR spectra were simulated with the EasySpin toolbox based on MATLAB [7].

Fluorescence spectra were obtained using a Perkin Elmer (Beaconsfield, UK) LS-50B luminescence spectrometer equipped with a pulsed xenon lamp (half peak height $<10 \mu \mathrm{s}, 60 \mathrm{~Hz}$ ), an R928 photomultiplier tube, and a computer working with FLWinlab.

\subsection{Synthesis of $\left.\mathrm{Na}_{4}[\mathrm{VO} \text { (baicalin) })_{2}\right] \cdot 6 \mathrm{H}_{2} \mathrm{O}, V^{I V} \mathrm{O}$ (baic)}

$\mathrm{VOCl}_{2}$ (50\% aqueous solution, $0.125 \mathrm{mmol}$ ) was added to a hot ethanolic solution $(30 \mathrm{~mL})$ of baicalin $(0.25 \mathrm{mmol})$.The solution was warmed $\left(60^{\circ} \mathrm{C}\right)$ and stirred for $1 \mathrm{~h}$, and the $\mathrm{pH}$ was adjusted to 9 by addition of a $\mathrm{NaOH}$ solution. The suspension was filtered and the green powder, characterized as $\left.\mathrm{Na}_{4}[\mathrm{VO} \text { (baicalin) })_{2}\right] \cdot 6 \mathrm{H}_{2} \mathrm{O}\left(\mathrm{V}^{\mathrm{IV}} \mathrm{O}\right.$ (baic)), was washed three times with absolute ethanol and dried in an oven at $60{ }^{\circ} \mathrm{C}$. Anal. calcd. For $\mathrm{C}_{42} \mathrm{H}_{42} \mathrm{O}_{29} \mathrm{VNa}_{4}$ : C43.7, H3.6, V 4.4, Na 8.0. Found: C43.6, H3.5, V 4.5, Na 8.2\%. Thermogravimetric analysis (oxygen atmosphere, velocity, $50 \mathrm{~mL} / \mathrm{min})$ : In a first step $\left(30-110{ }^{\circ} \mathrm{C}\right.$ ) the six water molecules are lost (9.5\% exp, 9.4\% calcd.). Diffuse reflectance: $440 \mathrm{~nm}, 660 \mathrm{~nm}$ (sh), $813 \mathrm{~nm}$.

\subsection{Spectrophotometric titrations and stability studies}

To establish the stoichiometry of the complex in solution the molar ratio method was applied. A solution of baicalin ( $\mathrm{MeOH}, 4 \times 10^{-5} \mathrm{M}$ ) was prepared and its electronic spectrum recorded. The absorption spectra of different methanolic solutions of $4 \times 10^{-5} \mathrm{M}$ baicalin and $\mathrm{VOCl}_{2}$ in ligand-to-metal molar ratios from 10 to 0.5 (pH 9.0, maintained by the addition of $\mathrm{NaOH}$ and $\mathrm{N}_{2}$ atmosphere) were measured. Plots of the absorbance of each solution at $316 \mathrm{~nm} v$ s the ligand-tometal ratios allowed the stoichiometric determinations. Stability studies have been performed measuring the variation of the $\mathrm{V}^{\mathrm{IV}} \mathrm{O}$ (baic) electronic absorption spectra with time. The dissolution of the complex was performed in DMSO, under nitrogen atmosphere.

\subsection{Antioxidant properties}

The superoxide dismutase (SOD) activity was examined indirectly using the nitroblue tetrazolium (NBT) assay. The indirect determination of the activity of baicalin and the $\mathrm{V}^{\mathrm{IV}} \mathrm{O}$ (baic) was assayed by their ability to inhibit the reduction of NBT by the superoxide anion generated by the phenazine methosulfate (PMS) and reduced nicotinamide adenine dinucleotide (NADH) system. As the reaction proceeded, the formazan color developed and a change from yellow to blue was observed which was associated with an increase of the intensity of the band at $560 \mathrm{~nm}$ in the absorption spectrum. The system contained $0.5 \mathrm{~mL}$ of sample, $0.5 \mathrm{~mL}$ of $1.40 \mathrm{mM}$ NADH and $0.5 \mathrm{~mL}$ of $300 \mu \mathrm{M} \mathrm{NBT}$, in $0.1 \mathrm{M}$ $\mathrm{KH}_{2} \mathrm{PO}_{4}-\mathrm{NaOH}$ buffer ( $\mathrm{pH} 7.5$ ). After incubation at $25^{\circ} \mathrm{C}$ for $15 \mathrm{~min}$, the reaction was started by adding $0.5 \mathrm{~mL}$ of $120 \mu \mathrm{M}$ PMS. Then, the reaction mixture was incubated for $5 \mathrm{~min}$. Each experiment was performed in triplicate and at least three independent experiments were performed in each case. The amount of baicalin or $\mathrm{V}^{\mathrm{IV}} \mathrm{O}$ (baic) that gave a $50 \%$ inhibition $\left(\mathrm{IC}_{50}\right.$ ) was obtained by plotting the percentage of inhibition versus the negative log of the concentration of the tested solution.

The capacity of the compounds to scavenge hydroxyl radicals (generated by the ascorbate-iron- $\mathrm{H}_{2} \mathrm{O}_{2}$ system) has been measured. Briefly, the reaction mixture contained $3.75 \mathrm{mM}$ 2-deoxyribose, $2.0 \mathrm{mM} \mathrm{H}_{2} \mathrm{O}_{2}$, $100 \mu \mathrm{M} \mathrm{FeCl}_{3}$, and $100 \mu \mathrm{M}$ EDTA without or with the tested compounds in $20 \mathrm{mM} \mathrm{KH}_{2} \mathrm{PO}_{4}-\mathrm{KOH}$ buffer, $\mathrm{pH}$ 7.4. The reaction was triggered by the addition of $100 \mu \mathrm{M}$ ascorbate and the mixture was incubated at $37^{\circ} \mathrm{C}$ for 30 min. Solutions of $\mathrm{FeCl}_{3}$, ascorbate, and $\mathrm{H}_{2} \mathrm{O}_{2}$ were made up in deaerated water immediately before use. The extent of deoxyribose degradation by hydroxyl radical was measured with the thiobarbituric acid method [8].

The inhibition of peroxyl radical was measured by generation of the radicals by the thermal decomposition of 2,2-azobis (2-amidinopropane) dihydrochloride (AAPH) [9]. AAPH was chosen due to its ability to generate free radicals at a steady rate for extended periods of time (half-life of $175 \mathrm{~h}$ ). The consumption of pyranine was followed spectrophotometrically by the decrease in absorbance at $454 \mathrm{~nm}$ with a thermostated cell at $37{ }^{\circ} \mathrm{C}$. The reaction solutions contained AAPH $(50 \mathrm{mM})$, pyranine $(50 \mu \mathrm{M})$ and several concentrations of the tested compounds. The delay of pyranine consumption (lag phase) was calculated as the time before the consumption of pyranine started (notable reductions in absorbance [10].

The antiradical activity of baicalin and $\mathrm{V}^{\mathrm{IV}} \mathrm{O}$ (baic) was also measured in terms of the capacity of the compounds to scavenge DPPH $\bullet(1,1$ diphenyl-2-picrylhydrazyl) radicals. The measurements were performed in triplicate using a modified method of Yamaguchi et al. [11]. A methanolic solution of ( $\left.\mathrm{DPPH}^{*}\right)$ ( $4 \mathrm{~mL}, 40 \mathrm{ppm}$ ) was added to $1 \mathrm{~mL}$ of the antioxidant solutions in $0.1 \mathrm{M}$ tris(hydroxymethyl)aminomethane- $\mathrm{HCl}$ buffer ( $\mathrm{pH} 7.1$ ) at $25^{\circ} \mathrm{C}$, giving a final concentration of $10 \mu \mathrm{M}$. After $60 \mathrm{~min}$ in the dark, the absorbance at $517 \mathrm{~nm}$ was measured and compared with the absorbance of the control prepared in a similar way without the addition of the antioxidants (this value was assigned arbitrarily as $100 \%)$. 


\subsection{A549 cell line assays}

\subsubsection{Cell culture}

Human lung cancer cell line A549 was obtained from ABAC (Argentinean Cell Bank Association INEVH, Pergamino, Buenos Aires, Argentina). Cells were maintained at $37^{\circ} \mathrm{C}$ in a $5 \%$ carbon dioxide atmosphere using DMEM supplemented with $100 \mathrm{U} / \mathrm{mL}$ penicillin, $100 \mu \mathrm{g} \mathrm{mL}^{-1}$ streptomycin and $10 \%(\mathrm{v} / \mathrm{v})$ fetal bovine serum as the culture medium. When 70-80\% confluence was reached, cells were subcultured using TrypLE ${ }^{\mathrm{TM}}$ from Gibco (Gaithersburg, MD, USA), free phosphate buffered saline (PBS) $\left(11 \mathrm{mM} \mathrm{KH}_{2} \mathrm{PO}_{4}, 26 \mathrm{mM}\right.$ $\mathrm{Na}_{2} \mathrm{HPO}_{4}, 115 \mathrm{mM} \mathrm{NaCl}, \mathrm{pH}$ 7.4). For the experiments, cells were grown in multi-well plates. When cells reached $70 \%$ confluence, the monolayers were washed twice with DMEM and then incubated with the different compounds.

2.5.2. MTT (3-(4,5-dimethylthiazol-2-yl)-2,5diphenyltetrazolium bromide) assay

A549 cells were seeded at a density of $1 \times 10^{5} /$ well in 48 well plates, grown overnight and treated with either vehicle, baicalin, $\mathrm{V}^{\mathrm{IV}} \mathrm{O}$ (baic) or oxidovanadium(IV) at different concentrations in FBS free medium. Dimethyl sulfoxide has been used as the dissolution vehicle to yield a maximum final concentration of $0.5 \%$ in the treated well (Sigma-Aldrich, St. Louis, MO). After 24,48 or $72 \mathrm{~h}$ of incubation at $37{ }^{\circ} \mathrm{C}$, $100 \mu \mathrm{g} /$ well MTT (Sigma-Aldrich, St. Louis, MO) was added and incubated for $2 \mathrm{~h}$. The formazan products generated by cellular reduction of MTT were dissolved in DMSO and the optical density was measured at $450 \mathrm{~nm}$. All experiments were performed in triplicate. Data were presented as percentage of cell viability (\%) of the treated group with respect to the untreated cells (control) in which the viability is assumed to be $100 \%$. To evaluate the cell viability in the presence of different antioxidants, the cells were incubated with different concentrations of the baicalin and $\mathrm{V}^{\mathrm{IV}} \mathrm{O}$ (baic) plus a mixture of vitamins $\mathrm{C}$ and $\mathrm{E}$ ( $50 \mu \mathrm{M}$ each) or NAC ( $(N$-acetylcysteine, $5 \mathrm{mM})$ during $24 \mathrm{~h}$. Then, the MTT assay was performed.

\subsubsection{ROS measurements}

Intracellular reactive oxygen species (ROS) generation in the A549 cell line was measured by oxidation of $2^{\prime}, 7^{\prime}$-dichlorodihydrofluorescein diacetate (H2DCFDA) to 2',7'-dichlorofluorescein (DCF). Briefly, 24well plates were seeded with $5 \times 10^{4}$ cells per well and allowed to adhere overnight. Then, different concentrations of baicalin, oxidovanadium(IV) cation and $\mathrm{V}^{\mathrm{IV}} \mathrm{O}$ (baic) were added for $24 \mathrm{~h}$. Following the compounds treatment, media was removed and cells were loaded with $10 \mu \mathrm{M}$ H2DCFDA diluted in clear media for $30 \mathrm{~min}$ at $37^{\circ} \mathrm{C}$. Media were separated and the cell monolayers rinsed with PBS and lysated into $1 \mathrm{~mL} 0.1 \%$ Triton-X100. The cell extracts were then analyzed for the oxidized product DCF by fluorescence spectroscopy (excitation wavelength, $485 \mathrm{~nm}$; emission wavelength, $535 \mathrm{~nm}$ ), using a Perkin-Elmer LS 50B spectrofluorometer [12]. ROS generation in cells was measured in the presence of NAC, using the same assay as described above. Cells were pretreated with $5 \mathrm{mM}$ of NAC for $30 \mathrm{~min}$, followed by treatment with baicalin and $\mathrm{V}^{\mathrm{IV}} \mathrm{O}$ (baic) at different concentrations for additional $24 \mathrm{~h}$.

\subsubsection{Cell morphology}

To evaluate the morphology of the cells, they were grown in six well/ plates and incubated overnight with fresh serum-free DMEM plus 0 (basal), 10 and $100 \mu \mathrm{M}$ solutions of the complex. The monolayers were subsequently washed twice with PBS, fixed with methanol and stained with 1:10 dilution of Giemsa for $10 \mathrm{~min}$. Next, they were washed with water and the morphological changes were examined by light microscopy.

\subsection{Toxicological assays}

\subsubsection{Artemia salina test}

For the determination of the acute toxicity of the metal, the ligand baicalin, $\mathrm{VOCl}_{2}$ and the $\mathrm{V}^{\mathrm{IV}} \mathrm{O}$ (baic) complex in brine shrimp, eggs of $\mathrm{A}$. salina were incubated in a hatching chamber with artificial seawater at 20 $30{ }^{\circ} \mathrm{C}$ (One liter of seawater contains: $\mathrm{NaCl}, 23 \mathrm{~g} ; \mathrm{MgCl}_{2} \cdot 6 \mathrm{H}_{2} \mathrm{O}, 11 \mathrm{~g}$; $\mathrm{Na}_{2} \mathrm{SO}_{4}, 4 \mathrm{~g} ; \mathrm{CaCl}_{2} \cdot 2 \mathrm{H}_{2} \mathrm{O}, 1.3 \mathrm{~g} ; \mathrm{KCl}, 0.7 \mathrm{~g}$ ) [13]. The $\mathrm{pH}$ was adjusted to 9.0 using $\mathrm{Na}_{2} \mathrm{CO}_{3}$ to avoid risk of death to the Artemia larvae by the decrease of $\mathrm{pH}$ during incubation [5]. After $24 \mathrm{~h}$, the larvae (nauplii) were extracted and counted using a micropipette. For the oxidovanadium(IV) cation, the ligand baicalin and the $\mathrm{V}^{\mathrm{IV}} \mathrm{O}$ (baic) complex, six concentrations (in triplicate) were tested in order to determine the dose-response relationship and negative (distilled water) and a positive $\left(\mathrm{K}_{2} \mathrm{Cr}_{2} \mathrm{O}_{7}\right)$ controls were used. Concentrations tested were $300,150,75,37.5,18.75$, and $9.37 \mu \mathrm{g} \mathrm{mL}^{-1}$. The selected concentrations were in the order of those used for the anticancer determinations. The wells containing the sample and 10 larvae of brine shrimp, including the control groups, were filled to a total volume of $100 \mu \mathrm{L}$ with artificial seawater. After $24 \mathrm{~h}$, live larvae were counted and the median lethal concentration $\left(\mathrm{LC}_{50}\right)$ values were estimated.

\subsubsection{Ames test}

The mutagenic potential of novel drugs needs to be investigated because some chemical agents which show mutagenicity can induce cancer [14]. Mutagenicity of the compounds was evaluated by the Salmonella/microsome assay that is based on the plate-incorporation method proposed by Maron and Ames [15], using Salmonella typhimurium TA98. The test strain was obtained from frozen culture and were grown overnight for $12-14$ h at $37{ }^{\circ} \mathrm{C}$ in Mueller Hinton broth. The different concentrations of the metal, the ligand baicalin and the $\mathrm{V}^{\mathrm{IV}} \mathrm{O}$ (baic) complex $(300,150,75,37.5$ and $18.75 \mu \mathrm{g} /$ plate) were added to $2 \mathrm{~mL}$ of top agar mixed with $100 \mu \mathrm{L}$ of bacterial culture (1-2 $\times 10^{8}$ cells $\left.\mathrm{mL}^{-1}\right)$ adding this mixture to a plate with minimal agar. These plates were incubated at $37^{\circ} \mathrm{C}$ for $48 \mathrm{~h}$ and the number of His + revertant colonies was counted. The selected concentrations were in the order of those used for the anticancer determinations. All experiments were made in duplicate. The Mutagenic index (MI) was calculated as the average number of revertants per plate divided by the average number of revertants per plate from the negative control for each dose.

\subsection{Bovine serum albumin (BSA) interaction}

BSA was dissolved in Tris- $\mathrm{HCl}(0.1 \mathrm{M}, \mathrm{pH} 7.4)$ buffer to attain a final concentration of $6 \mu \mathrm{M}$. Solutions of baicalin and $\mathrm{V}^{\mathrm{IV}} \mathrm{O}$ (baic) were added dropwise to the BSA solution and left to rest to ensure the formation of homogeneous solutions with concentrations ranging from 2 to $100 \mu \mathrm{M}$ with an incubation time of $1 \mathrm{~h}$. The fluorescence intensity was measured (excitation at $280 \mathrm{~nm}$ ) at 298, 303 and 310 K. For each sample and concentration, three independent replicates were performed. The measurements were carried out on a Perkin-Elmer LS-50B luminescence spectrometer (Beaconsfield, England) equipped with a pulsed xenon lamp (half peak height $<10 \mathrm{ls}, 60 \mathrm{~Hz}$ ), an R928 photomultiplier tube and a computer working with FLWinLab software. Both excitation and emission slits were set at $10 \mathrm{~nm}$ throughout this study.

\section{Results and discussion}

\subsection{Solid characterization of the complex}

\subsubsection{Vibrational spectroscopy}

The vibrational FTIR spectral data of the solids baicalin, its sodium salt (Na-baicalin) and $\mathrm{V}^{\mathrm{IV}} \mathrm{O}$ (baic) in $\mathrm{KBr}$ pellets is displayed in Table S1. Two components have been considered to discuss the vibrational 
spectrum of baicalin (the glucuronide of baicalein): glucuronic acid and the flavonoid moiety.

At the $\mathrm{pH}$ value of the preparative $(\mathrm{pH}=9)$ the deprotonation of the aliphatic hydroxylic acids has not been considered in this discussion because the ionization of these groups occurs at the remote part of the $\mathrm{pK}$ scale [16]. The aromatic hydroxylic acids showed increased acidic strength, due to the combined actions of both the electron-attracting inductive effect of the aromatic ring and the mesomeric effect. Therefore, in $V^{I V} O$ (baic) three acidic hydrogen atoms were removed and the first deprotonation has been assigned to the carboxylic acid and the second and third ionizations to the 5-OH and 6-OH groups. Despite the more accurate designation of baicalin must be $\mathrm{H}_{3}$ baic we will refer to the deprotonated ligand herein as baic or baicalin.

The carbonyl stretching mode of the carboxylic acid of the glucuronic moiety has been assigned to the very strong intense band at $1728 \mathrm{~cm}^{-1}$. Upon deprotonation of the $\mathrm{COOH}$ group, the carboxylate group was formed and the two $\mathrm{C}-\mathrm{O}$ bonds became equivalent showing two stretching bands, $v_{\text {as }}\left(\mathrm{COO}^{-}\right)$at $1583 \mathrm{~cm}^{-1}$ (NaBaic) and $1593 \mathrm{~cm}^{-1}(\mathrm{~V}-$ ${ }^{\mathrm{IV}} \mathrm{O}$ (baic) ) and $v_{\mathrm{s}}\left(\mathrm{COO}^{-}\right)$at $1456 \mathrm{~cm}^{-1}$ and $1450 \mathrm{~cm}^{-1}$ for NaBaic and $\mathrm{V}^{\mathrm{IV}} \mathrm{O}$ (baic), respectively. The positions of these bands were an indication that this group was not involved in the coordination with the metal center because the bands associated to the carboxylate anion of the sodium salt and the oxidovanadium(IV) complex appeared at the same positions. Then, it can be concluded that the carboxylate group of the deprotonated baicalin ligand did not bind to the oxidovanadium(IV) cation.

The other carbonyl $\mathrm{C}=0$ stretching band is located at $1660 \mathrm{~cm}^{-1}$ for baicalin has been assigned to the stretching vibration of the $\mathrm{C} 4=0$ group of ring B [17]. It has been reported that several metal ions coordinated to baicalin through this group increased its bond order and then a shift of the band to the red was observed in the infrared spectrum [18]. The shoulder located at $1662 \mathrm{~cm}^{-1}$ for the $\mathrm{V}^{\mathrm{IV}} \mathrm{O}$ (baic) complex indicated that the oxidovanadium(IV) cation did not interact directly with this group.

From Table S1 it can be seen that the major spectral shifts of the ligand when the interaction with the metal took place were the bands assigned to stretching and bending modes of the $\mathrm{C}-\mathrm{O}$ and $\mathrm{C}-\mathrm{OH}$ groups respectively. In particular the band assigned to $\mathrm{C} 5-\mathrm{O} 5$ stretching shifted to the red when the $\mathrm{H}$ atom of the $\mathrm{OH}$ group is replaced by the $\mathrm{V}=\mathrm{O}$ group, indicating an interaction of the metal ion with this group [19].

The $\mathrm{V}=\mathrm{O}$ stretching band located at relative low frequencies (925 $\mathrm{cm}^{-1}$ ) was evidenced by a coordination of this cation through cis-deprotonated oxygen atoms [3]. Then it can be concluded that the oxidovanadium(IV) cation interacted with the flavonoid through chelation with the two deprotonated $\mathrm{OH}$ groups located at the $\mathrm{C} 5$ and $\mathrm{C} 6$ atoms at ring $\mathrm{A}$. This interaction produced a resonance of the pi system of $\mathrm{V}=\mathrm{O}$ moiety with the ring $\mathrm{A}$ of the ligand and therefore the $\mathrm{V}=\mathrm{O}$ bond increased in length. This conclusion is supported by the measurements of the EPR spectra (see below).

\subsubsection{Electron paramagnetic resonance (EPR spectroscopy)}

To obtain a deeper insight into the environment of the oxidovanadium(IV) ion, EPR spectroscopic measurements were performed. The spectrum was obtained working with the microcrystalline powder at $293 \mathrm{~K}$ (Fig. 2). The EPR spectrum of the $\mathrm{V}^{\mathrm{IV}} \mathrm{O}$ (baic) gave an eight-line hyperfine splitting pattern due to the unpaired electron of the ${ }^{51} \mathrm{~V}$ nucleus $(I=7 / 2)$, generally being indicative of the presence of only one mononuclear oxidovanadium(IV) species in the solid complex. The powder experimental spectrum can be well simulated assuming gand A-matrices with axial symmetry. The simulation (Fig. 2) predicted that the observed signal originated from a vanadium chromophore was consistent with the oxidovanadium(IV) ion in a nearly axial or pseudoaxial ligand field. The experimental parameters were $g_{z}=$ $\mathrm{g}_{/ /}=1.9565 ; \mathrm{A}_{\mathrm{z}}=\mathrm{A}_{/ /}=154.7 \times 10^{-4} \mathrm{~cm}^{-1} ; \mathrm{g}_{\mathrm{x}}=\mathrm{g}_{\mathrm{y}}=\mathrm{g}_{\perp}=$ 1.9785; $A_{x}=A_{y}=A_{\perp}=50.8 \times 10^{-4} \mathrm{~cm}^{-1}$. To calculate the magnitude

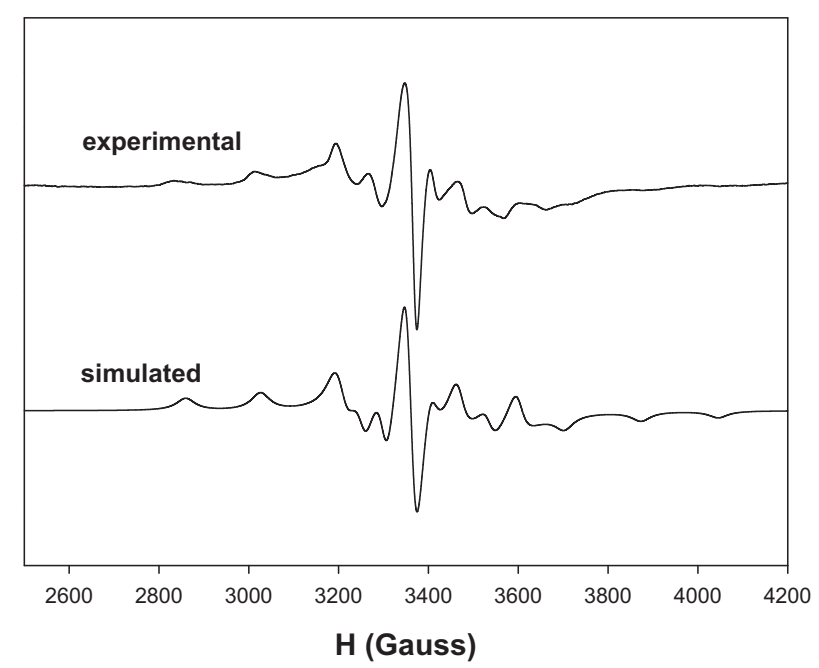

Fig. 2. Experimental and simulated room-temperature powder electron paramagnetic resonance spectrum of the $\left.\mathrm{Na}_{4}[\mathrm{VO} \text { (baicalin })_{2}\right] \cdot 6 \mathrm{H}_{2} \mathrm{O}$ complex $\left(\mathrm{V}^{\mathrm{IV}} \mathrm{O}\right.$ (baic) ) measured at X-band, $293 \mathrm{~K}$, microwave frequency of $9.459 \mathrm{GHz}$.

of $A_{z}$, the additivity relationship for oxidovanadium(IV) complexes, $A_{z}=\sum n_{i} A_{z, i}$, introduced by Chasteen [20] has been used. In this equation, $\mathrm{n}_{\mathrm{i}}$ is the number of equatorial ligands of type $\mathrm{i}$ and $\mathrm{A}_{\mathrm{z}, \mathrm{i}}$ is the contribution to the parallel hyperfine coupling of the most probable coordination environment. This constant can provide the identity of the equatorial donor sets coordinated to the $\mathrm{V}(\mathrm{IV}) \mathrm{O}^{2+}$ cation because each donor group made a specific contribution and the sum of the contributions of the four equatorial ligands can be compared with the observed experimental value. Taking into account the probable and expected donor set, considering four $\mathrm{ArO}^{-}$groups with a contribution to $A_{z}=\mathrm{ArO}^{-}, 38.6 \times 10^{-4} \mathrm{~cm}^{-1}$, the $A_{z}$ value of $154.4 \times 10^{-4} \mathrm{~cm}^{-1}$ has been calculated, in agreement with the experimental one. A binding mode involving an equatorial coordination sphere with two oxygen atoms from two $\mathrm{ArO}^{-}$groups of each flavonoid moiety (from ring A) is then suggested. This coordination agreed with the well-known spectral features of bis chelated $\mathrm{V}(\mathrm{IV}) \mathrm{O}^{2+}$ complexes in which two 1,2diolate moieties are bound to oxidovanadium(IV). This $2 \mathrm{x}\left(\mathrm{O}^{-}, \mathrm{O}^{-}\right)$coordination mode of $\mathrm{V}(\mathrm{IV}) \mathrm{O}^{2+}$ was substantiated with sugars and their derivatives provided with at least a cis couple of deprotonated hydroxy groups [21].

Besides, it has been reported that the flavonoid baicalein (the aglycone of baicalin) also formed anionic $\mathrm{V}(\mathrm{IV}) \mathrm{O}^{2+}$ penta-coordinated complexes with square pyramidal geometry and $2 \mathrm{x}\left(\mathrm{O}^{-}, \mathrm{O}^{-}\right)$or "catechollike" coordination in solution at $\mathrm{pH}$ values higher than 7.4, bearing similar EPR parameters $\left(\mathrm{g}_{\mathrm{II}}=1.954 ; \mathrm{A}_{\mathrm{II}}=155.3 \times 10^{-4} \mathrm{~cm}^{-1}\right)$. This type of coordination has been described to occur through the $\mathrm{C}-\mathrm{O}^{-}$groups of ring $A$ in positions 6 and 7 (or 5 and 6 ) for baicalein. Herein, with the glycosidic linkage located at the 7 position, we could determine that the coordination of the ligand to the metal occurred unequivocally through the 5 and 6 groups of ring A [22].

Considering the elemental analysis of the compound and the FTIR and EPR data, we can conclude that the structure of the $\mathrm{V}^{\mathrm{IV}} \mathrm{O}$ (baic) complex agree with the schema depicted in Fig. 3.

\subsection{Solution studies}

\subsubsection{Solution EPR spectrum}

To determine whether the structure of the solid complex has been retained in solution the EPR spectrum (X-band) has also been measured from the dissolution of the solid complex in DMSO $(120 \mathrm{~K}, 1.25 \mathrm{mM})$. This solvent is generally used as a solvent in EPR measurements of $\mathrm{V}(\mathrm{IV})$ compounds because it allows for a glass-like solidification of (and thus maintenance if isotropic conditions in) the solution at low 


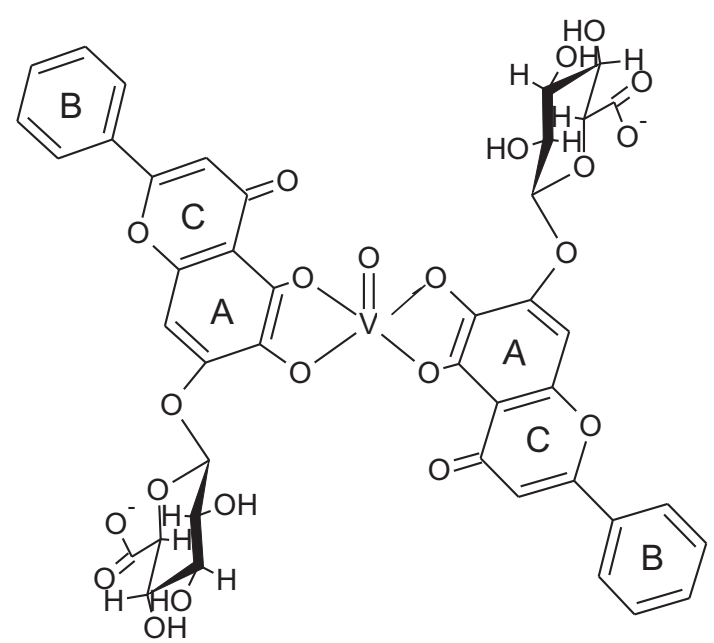

Fig. 3. Schematic representation of the complex $\mathrm{V}^{\mathrm{IV}} \mathrm{O}$ (baic).

temperatures. Besides, in addition, DMSO has been used to dissolve the solid complex for the biological measurements. The EPR signal (Fig. 4) shows the typical eight-line pattern spectrum for $\mathrm{V}(\mathrm{IV}) \mathrm{O}^{2+}$ systems. The solution experimental spectrum can be well simulated assuming g-and A-matrices with rhombic symmetry. This signal indicated the presence of single mononuclear species after the dissolution process. The spectral simulation (Fig. 4) predicted the formation of a $\mathrm{V}^{\mathrm{IV}} \mathrm{O}$ chromophore with spin Hamiltonian parameters $g_{z}=1.9505, g_{x}=1.9824$ and $\mathrm{g}_{\mathrm{y}}=1.9762$ and hyperfine coupling constants of $\mathrm{A}_{\mathrm{z}}=$ $155.1 \times 10^{-4} \mathrm{~cm}^{-1}, \mathrm{~A}_{\mathrm{x}}=39.3 \times 10^{-4} \mathrm{~cm}^{-1}$, and $\mathrm{A}_{\mathrm{y}}=$ $53.7 \times 10^{-4} \mathrm{~cm}^{-1}$. The calculated $A_{z}$ value is indicative of a coordination sphere similar to that of the solid complex, showing that the coordination sphere has been retained upon dissolution of the solid compound.

\subsubsection{UV-vis spectra}

The UV-vis absorption spectra of an aqueous solution of baicalin at different $\mathrm{pH}$ values have previously been reported [23]. Fig. S1 shows the spectral data obtained for a DMSO/EtOH (1/100 dissolution) of $5 \times 10^{-5} \mathrm{M}$ baicalin at different $\mathrm{pH}$ values.

At pH values lower than 6 two bands were observed at $279 \mathrm{~nm}$ (related to ring $A$, benzoyl, $\pi \rightarrow \pi^{*}$ ) and $316 \mathrm{~nm}$ (related to ring $\mathrm{B}$, cinnamoyl, $\mathrm{n} \rightarrow \pi^{*}$ ). The band of higher energy decreased its intensity from $\mathrm{pH}$ values 2 to 6 . The band related to ring B shifted to $306 \mathrm{~nm}$ at

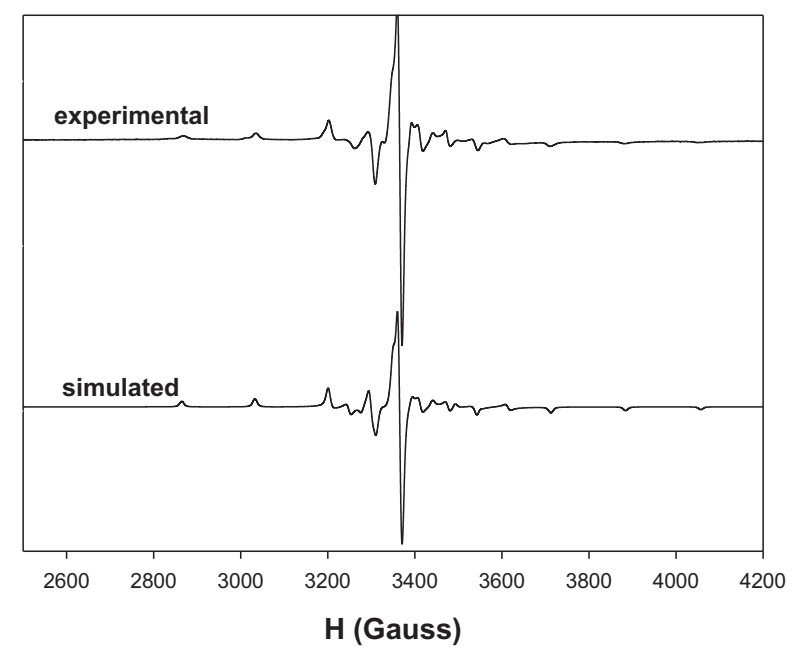

Fig. 4. Frozen solution EPR spectrum of $1.25 \mathrm{mM} \mathrm{V}^{\mathrm{IV}} \mathrm{O}$ (baic) in DMSO recorded at $120 \mathrm{~K}$, microwave frequency of $9.452 \mathrm{GHz}$, and the simulated spectrum.
$\mathrm{pH}$ values higher than 7 . The most important spectral changes appeared at $\mathrm{pH}$ values higher than 7 , in which the deprotonation of $\mathrm{C}-6 \mathrm{OH}$ group takes place generating a charge transfer band at $420 \mathrm{~nm}$ due to the donation of electrons to the ring. Because of the intramolecular hydrogen bond between $5-\mathrm{OH}-\mathrm{O} 4=\mathrm{C}$ groups that stabilize the $5-\mathrm{OH}$ group in its acidic form, the deprotonation of $\mathrm{C}-5 \mathrm{OH}$ group occurred at $\mathrm{pH}$ values higher than that of the hydroxyl group located on $\mathrm{C} 6$ (pKa1 $=$ 7.6, pKa2 = 10.1) [23]. The ionization of the carboxylic group (from the glucuronic moiety) occurred at pH values lower than 5 and did not affect the spectral pattern of baicalin. At a 100 times higher concentration of the flavonoid $\left(5 \times 10^{-3} \mathrm{M}\right)$ a new band at $c a .600 \mathrm{~nm}(\varepsilon$, $40 \mathrm{M}^{-1} \mathrm{~cm}^{-1}, \mathrm{pH}$ 8) has been detected (Fig. S2). At higher $\mathrm{pH}$ values, this band shifted to the blue denoting again that a new deprotonation occurred in the ligand (567 nm, $\varepsilon 34 \mathrm{M}^{-1} \mathrm{~cm}^{-1}$, pH 9). The UV-vis spectral changes of a DMSO/EtOH (1/100 dissolution ) of $\mathrm{VOCl}_{2} \cdot \mathrm{H}_{2} \mathrm{O}$ $\left(2.5 \times 10^{-5} \mathrm{M}\right)$ and baicalin $\left(5 \times 10^{-5} \mathrm{M}\right)$ at different $\mathrm{pH}$ values, depicted in Fig. S3, showed a similar pattern to that of the ligand. When the concentration of the solution is 100 times greater, the visible part of the electronic spectrum due to the oxidovanadium(IV) cation has been detected. Two bands at $610 \mathrm{~nm}\left(372 \mathrm{M}^{-1} \mathrm{~cm}^{-1}\right)$ and $795 \mathrm{~nm}\left(516 \mathrm{M}^{-1} \mathrm{~cm}^{-1}\right)$ were observed up to $\mathrm{pH} 5$ that resembles the spectrum of a carboxylate-oxidovanadium(IV) complex (Fig. S4) [24]. At pH 9 a single band is observed at $610 \mathrm{~nm}\left(204 \mathrm{M}^{-1} \mathrm{~cm}^{-1}\right)$. Despite the visible part of the spectrum at high energy is masked by the intense band of the UV region, this spectrum could be compared with that of a coordination sphere with $\left(\mathrm{O}^{-}, \mathrm{O}^{-}\right)$groups linked to the $\mathrm{V}(\mathrm{IV}) \mathrm{O}^{2+}$ cation [25]. The band of the ligand at $600 \mathrm{~nm}$ is of low intensity and did not interfere with these observations.

The spectrophotometric titration has been performed following the spectral variation of an ethanolic $4 \times 10^{-5} \mathrm{M}$ solution of baicalin at $\mathrm{pH} 9$ with the successive addition of $\mathrm{VOCl}_{2}$ at different ratios, at $316 \mathrm{~nm}$. A ligand-to-metal ratio 2-1 has been obtained in agreement with the stoichiometry of the solid complex (see Fig. 5).

The complex remained stable in a DMSO solution (no appreciable changes were observed in the UV-vis spectra) at least during $1 \mathrm{~h}$. Then it can be stated that the complex did not decompose during the manipulation of the solution for the biological studies.

\subsection{Antioxidant determinations}

The antioxidant properties have been evaluated by means on the capacity of the compounds to scavenge reactive oxygen species (ROS) in vitro. In addition, the capacity of the reduction of the concentration of

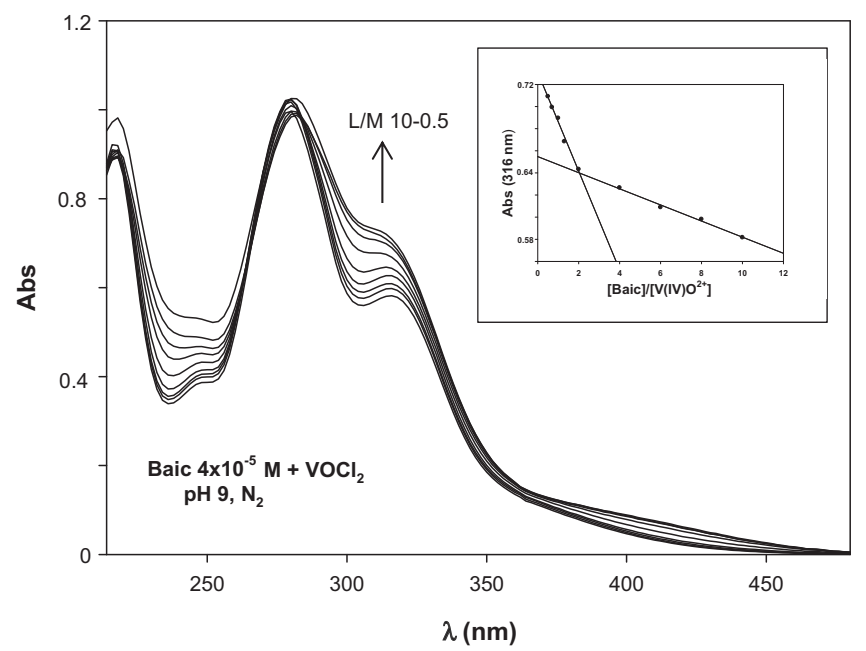

Fig. 5. UV-vis spectra of baicalin $\left(4 \times 10^{-5} \mathrm{M}\right)$ with the addition of $\mathrm{VOCl}_{2}$ in ligand-tometal ratios from 10.0 to 0.7 ( $\mathrm{pH} 9$ ), nitrogen atmosphere. Inset: spectrophotometric determination of $\mathrm{V}^{\mathrm{IV}} \mathrm{O}$ (baic) complex stoichiometry at $316 \mathrm{~nm}$ by the molar ratio method. 
Table 1

Antioxidant activities of baicalin, $\mathrm{V}^{\mathrm{IV}} \mathrm{O}$ (baic) and the oxidovanadium(IV) cation

\begin{tabular}{lllll}
\hline & $\mathrm{O}_{2}^{--}$ & $\begin{array}{l}\mathrm{DPPH}^{*} \% \\
\text { scavenge } \\
\left(\mathrm{IC}_{50}, \mu \mathrm{M}\right)\end{array}$ & $\begin{array}{l}\mathrm{OH}^{*} \% \\
\text { scavenge } \\
50 \mu \mathrm{M}\end{array}$ & $\begin{array}{l}\text { ROO* (lag } \\
\text { phase, min } \\
\text { at } 10 \mu \mathrm{M})\end{array}$ \\
\hline Baicalin & $>100$ & 95 & 59 & 4 \\
$\mathrm{~V}^{\mathrm{IV}}$ (baic) & 66 & 95 & 64 & 11 \\
$\mathrm{~V}(\mathrm{IV}) \mathrm{O}^{2+}$ & $15(\mathrm{SOD}, 0.21)$ & 14 & 18 & $<1$ \\
\hline
\end{tabular}

the DPPH`radical, ha@@@s been evaluated for comparative purposes (Table 1).

Baicalin did not display SOD activity while the complexation improved the capacity of dismutation of superoxide anion showing a moderate activity $\left(\mathrm{IC}_{50}=65.8 \mu \mathrm{M}\right)$ in comparison with the activities of the oxidovanadium(IV) cation $\left(\mathrm{IC}_{50}=15 \mu \mathrm{M}\right)$ and native SOD $\left(\mathrm{IC}_{50}=\right.$ $0.21 \mu \mathrm{M}$ ). The flavonoid showed a moderate activity on the peroxyl radical scavenging (phase lag of pyranine consumption of $4 \mathrm{~min}, 10 \mu \mathrm{M}$ ) while $\mathrm{V}^{\mathrm{IV}} \mathrm{O}$ (baic) increased the lag time and showed a better activity than the ligand and even than that of the good antioxidant compound Trolox. Both baicalin and $\mathrm{V}^{\mathrm{IV}} \mathrm{O}$ (baic) showed a similar antioxidant activity against $\mathrm{OH}^{\bullet}$ radicals scavenging $c a$. $60 \%$ of the radicals at a $50 \mu \mathrm{M}$ concentration and were able to scavenge $95 \%$ of the $\mathrm{DPPH} \mathrm{H}^{\circ}$ radicals at $50 \mu \mathrm{M}$. In addition to ensure that the antioxidant effects found for baicalin agree with previously reported values $[26,27]$ it can be seen that the complexation improved the antioxidant activity of the flavonoid in particular for the ROS superoxide and peroxyl radicals.

According to previous results [ 3 and references therein] when $\mathrm{V}=0$ coordinated to the $\mathrm{C} 4=\mathrm{O}$ and $\mathrm{C} 3-\mathrm{O}^{-}$or $\mathrm{C}^{-}-\mathrm{O}^{-}$groups, the electrons of the $\pi$ system of $\mathrm{V}=0$ are able to delocalize in the rings $\mathrm{A}$ and $\mathrm{C}$ (in the case that a double bond between $\mathrm{C} 2$ and $\mathrm{C} 3$ is present) and this group of flavonoids has previously been labeled as group I. In this group of VOflavonoid complexes (flavonoid = quercetin, naringenin, chrysin, silibinin, morin) the antioxidant properties of the complex are better than those for the parent flavonoid due to the high stability of the radical formed by the flavonoid upon interaction with an outer free radical. On the contrary, when the coordination involved $\mathrm{OH}$ groups in cis- position on ring $\mathrm{B}$ or a distant substituent of rings $\mathrm{B}$ or $\mathrm{C}$ (hesperidin, luteolin, diosmin, [28] the complex formation did not improve the antioxidant properties of the ligand. In the $\mathrm{V}^{\mathrm{IV}} \mathrm{O}$ (baic) complex the interaction occurred through the phenolate groups on ring $\mathrm{A}$, and then a

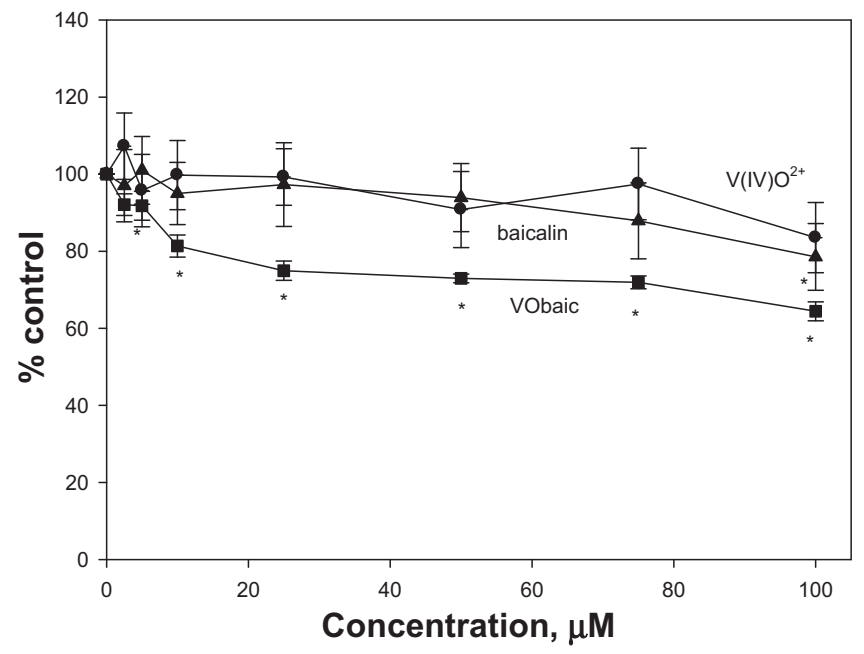

Fig. 6. Inhibitory effects of baicalin (triangles), $\mathrm{V}^{\mathrm{IV}} \mathrm{O}$ (baic) (squares) and oxidovanadium(IV) cation (circles) on A549 cell viability. The cell line was treated with various concentrations of the compounds for $24 \mathrm{~h}$. The results are expressed as the percentage of the control leve and represent the mean \pm the standard error of the mean (SEM) from three separate experiments. * significant values in comparison with the control level $(P<0.05)$.
Table 2

$\mathrm{IC}_{50}$ values of baicalin and $\mathrm{V}^{\mathrm{IV}} \mathrm{O}$ (baic) at 24,48 and $72 \mathrm{~h}$ incubation.

\begin{tabular}{llll}
\hline & $\mathrm{IC}_{50}(\mu \mathrm{M}), 24 \mathrm{~h}$ & $\mathrm{IC}_{50}(\mu \mathrm{M}), 48 \mathrm{~h}$ & $\mathrm{IC}_{50}(\mu \mathrm{M}), 72 \mathrm{~h}$ \\
\hline Baicalin & $>100$ & $>100$ & $77.4 \pm 2.7$ \\
$\mathrm{~V}^{\mathrm{IV}}$ O(baic) & $>100$ & $44.7 \pm 3.5$ & $21.7 \pm 1.3$ \\
\hline
\end{tabular}

$\pi$ electron delocalization is feasible, and an improvement of the antioxidant properties of the flavonoid upon complexation is observed.

\subsection{A549 cell line assays}

\subsubsection{Cell viability}

Baicalin inhibited different cancer cell lines growth like acute lymphocytic leukemia (ALL) [29], prostatic cancer cell lines [30] human (KU-1 and EJ-1), murine (MBT-2) bladder cancer cell lines [31] and A549 human lung cancer cells [32]. The cytotoxicity of baicalin, V${ }^{\mathrm{IV}} \mathrm{O}$ (baic) and oxidovanadium(IV) cation on A549 cell line was determined by MTT assay. As shown in Fig. 6, the oxidovanadium(IV) cation induced no cytotoxicity to human lung cancer cells at the tested concentrations. Baicalin behaved as a slightly anticancer agent, inhibiting $20 \%$ of cell viability at $100 \mu \mathrm{M}\left(\mathrm{IC}_{50}>100 \mu \mathrm{M}\right)$, as it was previously found [32]. The complex $\mathrm{V}^{\mathrm{IV}} \mathrm{O}$ (baic) exhibited its cytotoxic effect in a dose-response manner (the survival cells were $65 \%$ of the control at $100 \mu \mathrm{M})$. It can then be seen that the complexation improved the action of the free ligand, similar to previous determinations for copper and aluminium baicalin complexes [33].

When the time of incubation of the cells with the different compounds increased, an improvement of their anticancer effects has been observed (Table 2 ). At $72 \mathrm{~h}$ incubation an $\mathrm{IC}_{50}$ value of $77.4 \mu \mathrm{M}$ was found for baicalin, in agreement with previous results [34-36] and $21.7 \mu \mathrm{M}$ for $\mathrm{V}^{\mathrm{IV}} \mathrm{O}$ (baic). In all cases $\mathrm{V}^{\mathrm{IV}} \mathrm{O}$ (baic) improved the action of the ligand displaying a time-dependent behavior with low $\mathrm{IC}_{50}$ values. Therefore, it can be demonstrated that the exposition time affected the cell viability and at $72 \mathrm{~h}$ incubation the complex showed a strong deleterious effect on the A549 cell line.

\subsubsection{Mechanism of action}

Reactive oxygen species (ROS) like hydroxyl radical $\left(\mathrm{OH}^{\bullet}\right)$, superoxide anion radical $\left(\mathrm{O}_{2}^{\bullet-}\right)$, hydrogen peroxide $\left(\mathrm{H}_{2} \mathrm{O}_{2}\right)$, peroxyl radicals $\left(\mathrm{ROO}^{\bullet}\right)$, nitric oxide $\left(\mathrm{NO}^{\bullet}\right)$ and reactive nitrogen species (RNS) are

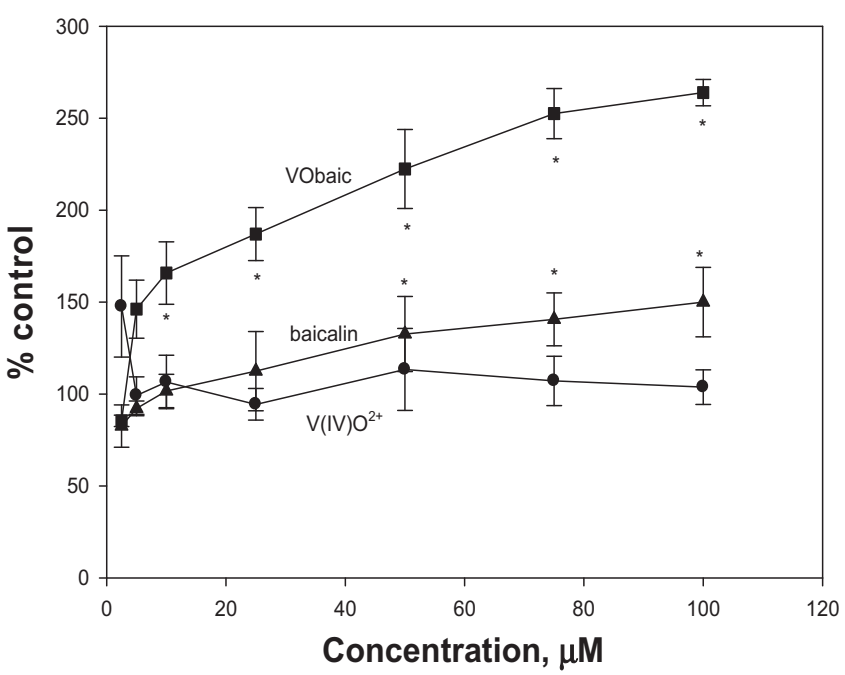

Fig. 7. Effect of baicalin, $\mathrm{V}^{\mathrm{IV}} \mathrm{O}$ (baic) and oxidovanadium(IV) cation on $\mathrm{H} 2 \mathrm{DCFDA}$ oxidation to DCF. A549 cells were incubated at $37^{\circ} \mathrm{C}$ in the presence of $10 \mu \mathrm{M}$ H2DCFDA. The values are expressed as the percentage of the control level and represent the mean \pm SEM.* significant values in comparison with the control level $(P<0.05)$. 

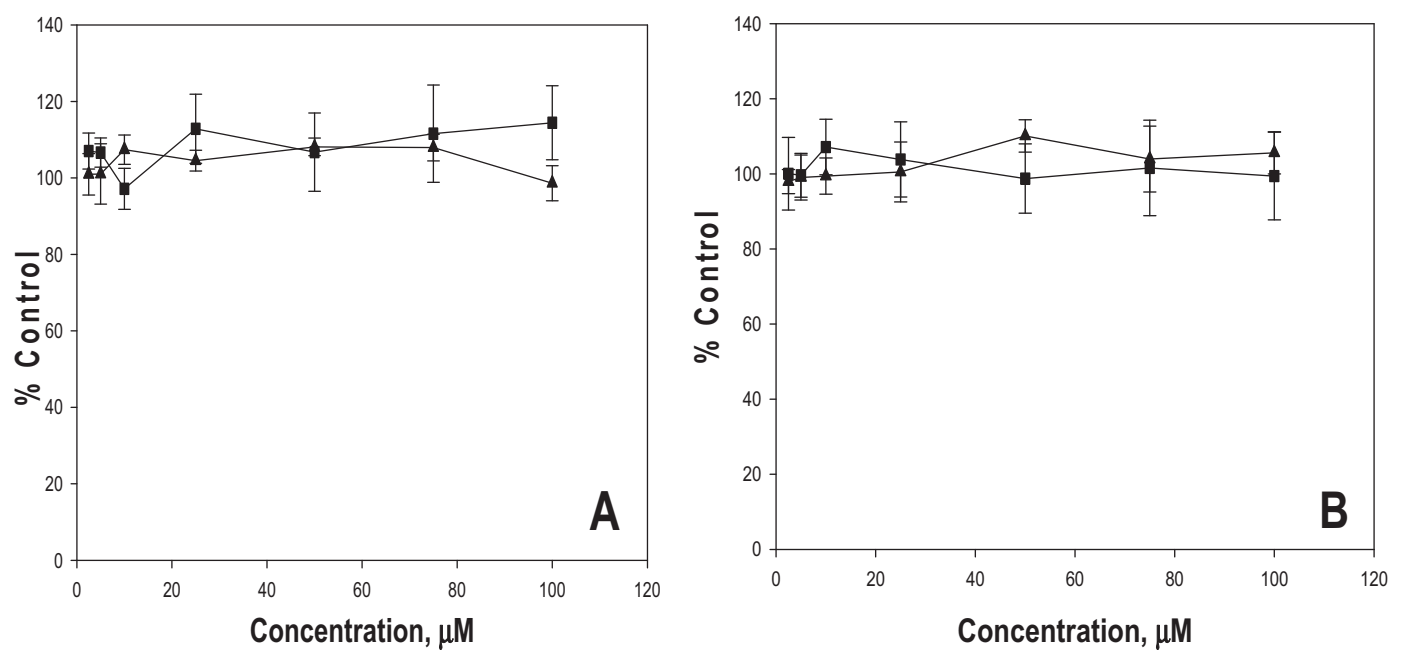

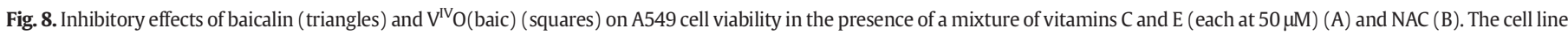

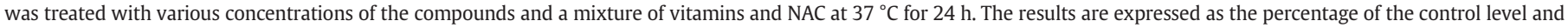
represent the mean \pm the standard error of the mean (SEM) from three separate experiments. All values are not different to the control level $(P<0.05)$.

spontaneously generated in cells during metabolism and are capable of causing oxidative damage when produced in excessive quantities. ROS have been implicated in the pathogenesis of a wide variety of human diseases that alter the function of genetic apparatus and can oxidize and damage nucleic acids, proteins and lipids, which are the major components of cell membranes and also lead to cell death [37]. For a better understanding of the possible mechanisms involved in the cytotoxicity of the compounds in the A549 cell line, we evaluated the effect of baicalin and $\mathrm{V}^{\mathrm{IV}} \mathrm{O}$ (baic) on cellular ROS generation through the oxidation of the H2DCFDA probe. The results showed that oxidovanadium(IV) cation did not increase the cellular ROS levels (Fig. 7) and $\mathrm{V}^{\mathrm{VV}} \mathrm{O}$ (baic) produced an increment of ROS levels in a dose-dependent manner with statistical differences in the whole range of concentrations $(p<0.05)$. At $100 \mu \mathrm{M}$ concentration the complex caused ca. $260 \%$ of ROS increment over the untreated cells and baicalin produced a low increment of ROS levels (150\% at $100 \mu \mathrm{M})$. The increase of the reactive oxygen species with the concentration of the added compounds is consistent with the higher inhibition of the cell viability produced by the flavonoid and the complex in a dose response manner.

\subsubsection{Effect of ROS on cell viability}

Free radicals either produced from the normal cell metabolisms or from external sources, are scavenged by the second line of defense of the body: non-enzymatic antioxidants namely, vitamin $\mathrm{C}$ (ascorbic acid), vitamin E (tocopherol), and reduced glutathione [38]. Vitamin C scavenges superoxide, hydroxyl, hydrogen peroxide and singlet oxygen radicals and is oxidized by a variety of other oxidants such as halogens, quinones, and phenoxyl radicals. Vitamin $\mathrm{E}$ is the most important lipidsoluble antioxidant in humans. It is a scavenger of peroxyl radicals and therefore inhibits the chain reactions in lipid peroxidation [39]. To determine the effects of ROS on the cell viability, human lung cancer cells were incubated with baicalin and $\mathrm{V}^{\mathrm{IV}} \mathrm{O}$ (baic) and natural antioxidants (mixture of vitamins $\mathrm{C}$ and $\mathrm{E}$ ). It can be observed from Fig. 8A that baicalin and $\mathrm{V}^{\mathrm{IV}} \mathrm{O}$ (baic), behaved like the untreated cells, being the cell viabilities like those of the basal-like cells. The same results were obtained using other scavenger of free radicals, $\mathrm{N}$-acetyl-L-cysteine (NAC) Fig. 8B. It can be seen that while the added compounds generate oxidative stress in the cell lines producing the inhibition of the cellular viability, the incubation of the compounds with the addition of strong antioxidants prevent cellular death by the scavenge of the generated free radicals.

To confirm this hypothesis the cellular ROS levels were measured in the cell lines again with the pre-treatment of $\mathrm{N}$-acetyl-L-cysteine (NAC) and baicalin or $\mathrm{V}^{\mathrm{IV}} \mathrm{O}$ (baic). It can be seen in Fig. 9 that the ROS levels were completely reduced to the natural ROS contents of the untreated cancer cell line. The comparison with the results shown in Fig. 7 suggested that the oxidative stress generated by the action of the baicalin and $\mathrm{V}^{\mathrm{IV}} \mathrm{O}$ (baic) in the absence of antioxidant agents is a possible mechanism of cell death, in agreement with some results reported for the flavonoid baicalin $[40,41]$.

\subsubsection{Morphological changes}

Taking into account the cytotoxic effects of $\mathrm{V}^{\mathrm{IV}} \mathrm{O}$ (baic) on the human lung cancer cells we investigated its action on the cell morphology (Fig. 10). Most untreated A549 cells showed a pebble-like shape and cell-cell close adhesion [42]. Upon treatment with $100 \mu \mathrm{M} \mathrm{V} \mathrm{V}^{\mathrm{V}} \mathrm{O}$ (baic) for $24 \mathrm{~h}$ morphological changes were observed. The cells showed condensation of the cytoplasm and narrow protrusions appeared.

\subsection{Toxicological assays}

\subsubsection{Artemia salina Tests}

The brine shrimp test has been widely used to test the toxicity of a great variety of products. Although the substitution of laboratory animals for toxicity studies by $A$. salina needs further investigation, it has previously been demonstrated that toxicity assays studies on the $\mathrm{LC}_{50}$ of medicinal plant extracts using A. salina correlated well with the corresponding oral lethal dose $\left(\mathrm{LD}_{50}\right)$ in mice [43]. The mortality of brine shrimp for every concentration of $\mathrm{VOCl}_{2}$ is shown in Table 3. The

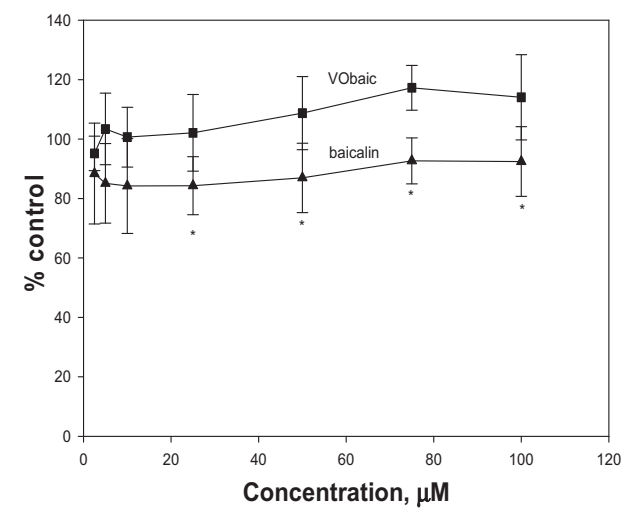

Fig. 9. Effect of $\mathrm{N}$-acetyl-L-cysteine (NAC, $5 \mathrm{mM}$ ) on ROS production induced by baicalin and $\mathrm{V}^{\mathrm{IV}} \mathrm{O}$ (baic). The values are expressed as a percentage of the control level and represent the mean \pm SEM. * significant values in comparison with the control level $(P<0.05)$. 


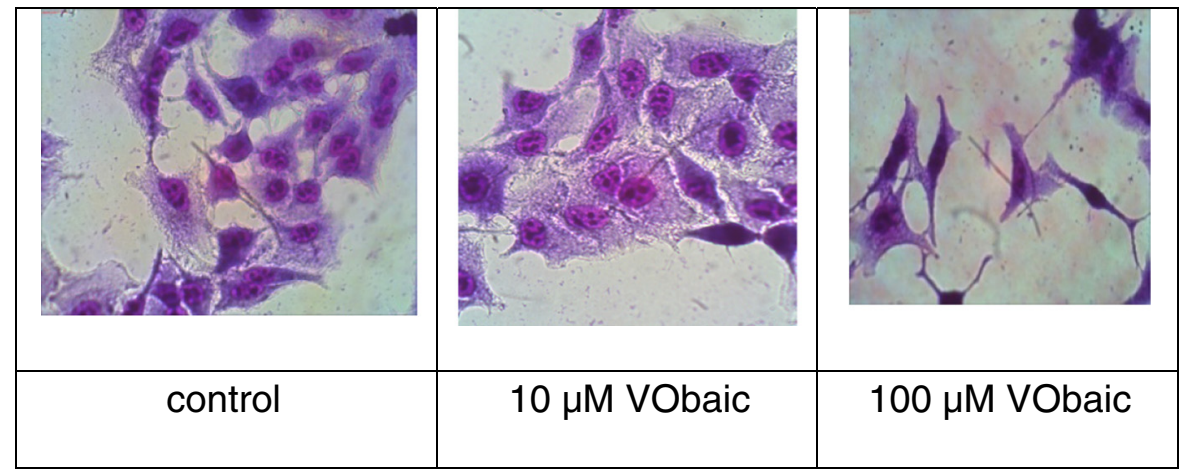

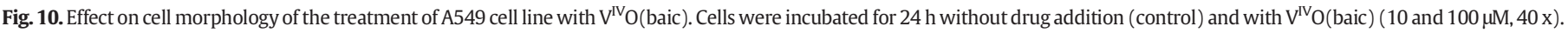

mortality increased in a dose-response manner and this linearity allowed us to determine $\mathrm{LC}_{50}$ value $(244 \mu \mathrm{M})$, which is the dose required to kill half of the members of the tested population. On the other hand, dead nauplii were not observed for the ligand baicalin and the $\mathrm{V}^{\mathrm{IV}} \mathrm{O}$ (baic) complex at the tested concentrations showing that the flavonoid and the complex did not exert toxic effects.

\subsubsection{Ames test}

The Artemia salina $\mathrm{L}$. test is useful for the screening of novel drugs in order to predict their toxicity and has shown a good correlation $(r=$ $0.85 p<0.05)$ with the assays in mice, suggesting that the brine shrimp bioassay is a useful alternative model [44]. The Ames Salmonella typhimurium assay has been used to identify substances that can produce genetic damage that leads to gene mutations. The test uses Salmonella strains with preexisting mutations that are not capable to synthesize histidine, and then are not able to grow or form colonies in its absence. Compounds with mutagenic potential may restore the genes function (reversion assay). Consequently, a positive test indicates that the compound is mutagenic and therefore may act as a carcinogen. A sample was considered positive when the mutagenic index (MI) was equal or $>2$ for at least one of the tested doses and if it had a reproducible dose-response curve [15]. It can be seen in Table 4 that the oxidovanadium(IV) cation, the ligand baicalin and the $\mathrm{V}^{\mathrm{IV}} \mathrm{O}$ (baic) complex did not exert mutagenic action on the tested strain. At the higher added concentrations ( 1 and $0.5 \mathrm{mM}$ ) the MI value of the oxidovanadium(IV) cation could not be detected because of the antimicrobial action exerted by $\mathrm{VOCl}_{2}$ against Salmonella typhimurium TA98. The mutagenic index value resulted lower than 2 in all the cases and showed that the tested substances could not induce an increase in the number of revertants. These results indicated that the oxidovanadium(IV) cation, the ligand baicalin and the V${ }^{\mathrm{IV}} \mathrm{O}$ (baic) complex did not induce frameshift mutations at the tested concentrations.

\subsection{Bovine serum albumin (BSA) interaction}

\subsubsection{Fluorescence quenching studies}

The interaction between biomacromolecules, especially those between plasma proteins and drugs, has been an interesting research

Table 3

Mortality produced by $\mathrm{VOCl}_{2}$ and $\mathrm{LC}_{50}$ estimated values using Artemia salina test.

\begin{tabular}{ll}
\hline $\mathrm{LC}_{50}$ value $\left(\mu \mathrm{g} \mathrm{mL}^{-1}\right) 33.71$ & \\
\hline$\left[\mathrm{VOCl}_{2}\right]\left(\mu \mathrm{g} \mathrm{mL}{ }^{-1}\right)$ & Mortality $(\%)$ \\
\hline 300 & 100 \\
150 & 100 \\
75 & 100 \\
37.5 & 46.7 \\
18.75 & 40 \\
9.37 & 20 \\
\hline
\end{tabular}

field in life sciences, chemistry, and clinical medicine. Bovine serum albumin (BSA) is used as the model protein for drug delivery because of its medical importance, abundance, low cost, ease of purification, unusual ligand-binding properties and that it is widely accepted in the pharmaceutical industry. The studies concerning the interaction and potential transport with bovine serum albumin were made with baicalin and $\mathrm{V}^{\mathrm{IV}} \mathrm{O}$ (baic) measuring the fluorescence intensity of the BSA before and after the addition of these compounds. The interaction with oxidovanadium(IV) cation was previously discussed [45]. It has been demonstrated that the increment of concentrations of $\mathrm{V}(\mathrm{IV}) \mathrm{O}^{2+}$ barely produced a $10 \%$ quenching at the higher tested concentration values.

On the knowledge that the protein has two tryptophan residues (located at positions 134 and 212, respectively) that possess intrinsic fluorescence [46] the strong fluorescence emission of BSA can be observed (Fig. 11). On the contrary, baicalin and $\mathrm{V}^{\mathrm{IV}} \mathrm{O}$ (baic) displayed almost no intrinsic fluorescence under the experimental conditions (data not shown). The fluorescence intensities of BSA decreased with the increase of the concentration of the added compounds, accompanied by a red shift of the maximum emission wavelengths in the fluorescence spectra indicating interactions between the compounds and the protein. The red shift of the emission band produced by the change in the environment sensed by the tryptophan in BSA suggested that tryptophan has been brought to more hydrophilic environment changing the secondary structure of the protein [47]. It can be observed that $\mathrm{V}^{\mathrm{IV}} \mathrm{O}$ (baic) led to total quenching at $40 \mu \mathrm{M}$ concentration and that baicalin quenched $c a$. $70 \%$ of the fluorescence intensity of BSA at the same concentration.

Table 4

Induction of His + revertants (Rev) in Salmonella typhimurium TA98 by the oxidovanadium(IV) cation, the ligand baicalin and the $\mathrm{V}^{\mathrm{IV}} \mathrm{O}$ (baic) complex without metabolic activation ( 59 mix).

\begin{tabular}{llll}
\hline & & \multicolumn{2}{l}{ S. typhimurium TA98 } \\
\cline { 3 - 4 } & Concentration $(\mu \mathrm{g} /$ plate $)$ & Rev/plate & MI $^{\mathrm{b}}$ \\
\hline Strain control & & $34.5 \pm 0.5$ & - \\
$\mathrm{VOCl}_{2}$ & 75 & $26 \pm 3$ & 0.75 \\
& 37.5 & $30 \pm 2$ & 0.87 \\
baicalin & 18.75 & $30 \pm 2$ & 0.87 \\
& 300 & $32 \pm 1$ & 0.93 \\
& 150 & $37.5 \pm 1.5$ & 1.09 \\
& 75 & $34 \pm 1$ & 0.98 \\
$\mathrm{~V}^{\mathrm{IV}}$ O(baic) & 37.5 & $45 \pm 1$ & 1.30 \\
& 18.75 & $35 \pm 1$ & 1.01 \\
& 300 & $33 \pm 2$ & 0.96 \\
& 150 & $30 \pm 1$ & 0.87 \\
& 75 & $31 \pm 1$ & 0.89 \\
& 37.5 & $25.5 \pm 0.5$ & 0.74 \\
& 18.75 & $24.5 \pm 0.5$ & 0.71
\end{tabular}

a Number of revertants/plate: mean of two independent experiments \pm SD.

b MI: mutagenic index (number of His + induced in the sample/number of spontaneous His + in the negative control) 

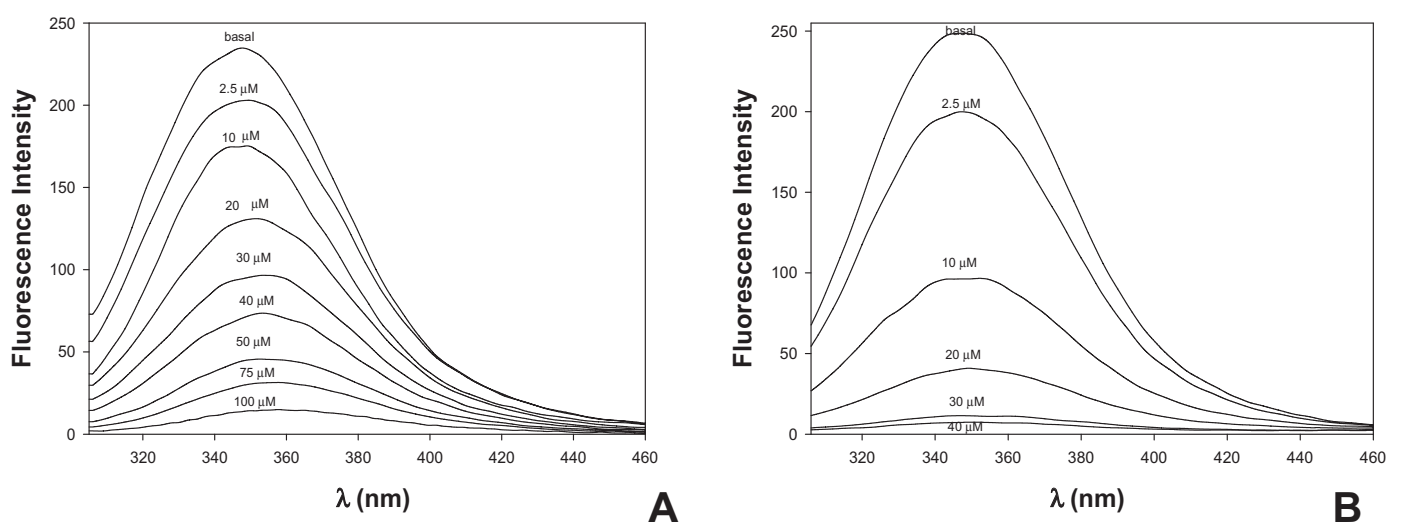

Fig. 11. The fluorescence spectra of $B S A$ at various concentrations of baicalin (A) and $\mathrm{V}^{\mathrm{IV}} \mathrm{O}$ (baic) (B). $\lambda_{\mathrm{ex}}=280 \mathrm{~nm},[\mathrm{BSA}]=6 \mu \mathrm{M}, T=310 \mathrm{~K}$.

To confirm the quenching mechanism the fluorescence data at different temperatures with the Stern-Volmer Eq. (1) have been analyzed, [48] using the following equation:

$\mathrm{F}_{0} / \mathrm{F}=1+\mathrm{K}_{\mathrm{q}} \tau_{0}[\mathrm{Q}]=1+\mathrm{K}_{\mathrm{SV}}[\mathrm{Q}]$

where $\mathrm{F}_{0}$ and $\mathrm{F}$ are the fluorescence intensities in the absence and presence of quencher, respectively; $\mathrm{K}_{\mathrm{q}}$ is the bimolecular quenching constant; $\tau_{0}$ is the lifetime of the fluorophore in the absence of quencher; [Q] is the concentration of quencher and $K_{s v}$ is the Stern-Volmer quenching constant which can be obtained from the slope of Eq. (1).

Fig. 12 displays the Stern-Volmer plots of the quenching of BSA fluorescence by baicalin (A) and $\mathrm{V}^{\mathrm{IV}} \mathrm{O}$ (baic) (B) at different temperatures. It can be observed that the plots largely deviated from linearity toward the $\mathrm{y}$-axis at concentrations higher than $30 \mu \mathrm{M}$. The upward curvature indicated that the quenching type is a combined quenching (both static and dynamic) [49] but at lower concentrations a single quenching (static or dynamic) probably takes place. The Stern-Volmer plots were used to elucidate these assumptions at lower concentrations, and a linear correlation has been obtained for both compounds (insets, Fig. $12 \mathrm{C}$ and $\mathrm{D}$, respectively). In Table 5 the calculated values of $\mathrm{K}_{\mathrm{sv}}$ are presented showing a decrease with temperature. When the bimolecular quenching constants $\mathrm{K}_{\mathrm{q}}$ are calculated using the well-known relationship ( $\mathrm{Kq}=\mathrm{Ksv} / \tau_{0}, \tau_{0}=10^{-8} \mathrm{~s}$, Table 5$)$, values much greater than the maximum dynamic quenching constant $2.0 \times 10^{10} \mathrm{M}^{-1} \mathrm{~s}^{-1}$ have been obtained. These results suggested that the interaction between the compounds and BSA most probably occurred by static quenching [50].

\subsubsection{Binding constants and the number of binding sites}

The determination of the level of compound binding with serum albumin is critical and will directly correlate with the transport, disposition, and in vivo efficacy of the compound. The value of $\mathrm{K}_{\mathrm{a}}$ is essential to understand the distribution of compounds in plasma since a weak binding can result in comparatively high concentrations of the drug in the plasma, resulting in a shorter life time while a strong binding can decrease the concentrations of compound in plasma, improving the pharmacological effect.

On the assumption that the fluorescence quenching of protein could be a static quenching process (complex formation between protein and quencher), the equilibrium between free and bound molecule could be given by the following Eq. (2)

$\log \left[\left(\mathrm{F}_{0}-\mathrm{F}\right) / \mathrm{F}\right]=\log \mathrm{K}_{\mathrm{a}}+\mathrm{n} \log [\mathrm{Q}]$

where $\mathrm{K}_{\mathrm{a}}$ and $\mathrm{n}$ are the binding constant and the number of binding sites, respectively. The $K_{a}$ and $n$ per BSA at different temperature acquired from the plots in Fig. 13 were listed in Table 5. It was found that the binding constant decreased with an increase in temperature, resulting in a reduction of the stability of the compound-BSA system. Comparing the binding constants of baicalin-BSA and $\mathrm{V}^{\mathrm{IV}} \mathrm{O}$ (baic)-BSA systems, it was found that the binding with the complex was stronger than that of the free ligand. The number of binding sites of the

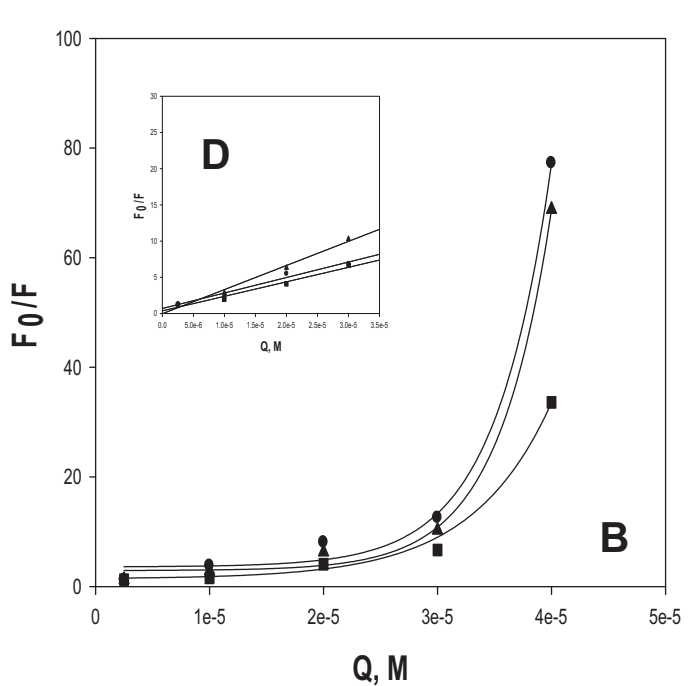

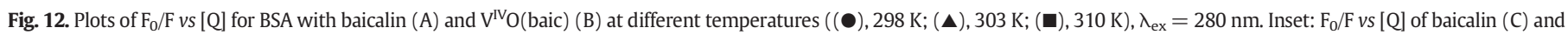
$\mathrm{V}^{\mathrm{IV}} \mathrm{O}$ (baic) (D). 
Table 5

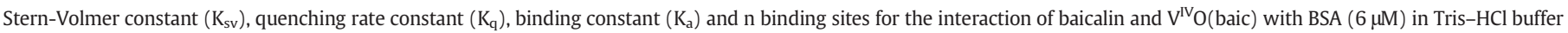
(0.1 M, pH 7.4).

\begin{tabular}{|c|c|c|c|c|c|c|}
\hline Compounds & $\mathrm{T}(\mathrm{K})$ & $\begin{array}{l}\mathrm{K}_{\mathrm{sv}}\left(\times 10^{4}\right) \\
\left(\mathrm{M}^{-1}\right)\end{array}$ & $r^{2}$ & $\begin{array}{l}\mathrm{K}_{\mathrm{q}}\left(\times 10^{12}\right) \\
\left(\mathrm{M}^{-1} \mathrm{~s}^{-1}\right)\end{array}$ & $\begin{array}{l}\mathrm{K}_{\mathrm{a}}\left(\times 10^{6}\right) \\
\left(\mathrm{M}^{-1}\right)\end{array}$ & $\mathrm{n}$ \\
\hline \multirow{3}{*}{ Baicalin } & 298 & $7.86 \pm 0.52$ & 0.98 & $7.86 \pm 0.52$ & $5.13 \pm 0.31$ & $1.39 \pm 0.06$ \\
\hline & 303 & $7.79 \pm 0.78$ & 0.98 & $7.79 \pm 0.78$ & $3.06 \pm 0.17$ & $1.35 \pm 0.03$ \\
\hline & 310 & $7.10 \pm 0.53$ & 0.99 & $7.10 \pm 0.53$ & $1.02 \pm 0.23$ & $1.25 \pm 0.02$ \\
\hline \multirow[t]{3}{*}{$\mathrm{V}^{\mathrm{IV}} \mathrm{O}$ (baic) } & 298 & $41.57 \pm 0.22$ & 0.99 & $41.57 \pm 0.22$ & $13.48 \pm 0.46$ & $1.39 \pm 0.05$ \\
\hline & 303 & $33.27 \pm 0.35$ & 0.99 & $33.27 \pm 0.35$ & $6.61 \pm 0.82$ & $1.33 \pm 0.07$ \\
\hline & 310 & $20.06 \pm 0.57$ & 0.97 & $20.06 \pm 0.57$ & $2.51 \pm 0.21$ & $1.26 \pm 0.03$ \\
\hline
\end{tabular}

$r^{2}$ is the correlation coefficient for the $K_{S V}$ values.

compounds with BSA ( $n=1.25-1.39$ ) was $c a .1 .0$ and corresponded to the binding sites with high affinity. These data suggested that baicalin and $\mathrm{V}^{\mathrm{IV}} \mathrm{O}$ (baic) can be stored and removed by BSA. Our results for $\mathrm{n}$ and $K_{a}$ agree with previous data reported for baicalin [51]. On the other hand it is important to mention that there are some discrepancies in the literature for the interaction of baicalin with albumin being the $\mathrm{K}_{\mathrm{sv}}, \mathrm{K}_{\mathrm{a}}$ and the thermodynamic parameters quite different from each other. These differences could be attributed to the different experimental conditions used in each determination (differences in albumin and flavonoid concentrations, albumin fractions and/or dissolution media) [51-53].

\subsubsection{Thermodynamic parameters}

The interaction forces between drugs and biomolecules may include electrostatic interactions, multiple hydrogen bonds, van der Waals interactions, hydrophobic and steric contacts within the antibody-binding site, etc. [54]. To infer the type of process of the interaction between baicalin and $\mathrm{V}^{\mathrm{IV}} \mathrm{O}$ (baic) with $\mathrm{BSA}$, thermodynamic parameters, including enthalpy change $(\Delta H)$, entropy change $(\Delta S)$ and free energy change $(\Delta G)$ were investigated. If $\Delta H$ does not vary significantly over the temperature range studied, then its value and that of $\Delta S$ can be evaluated from the van't Hoff Eq. (3):

$\ln \mathrm{K}_{\mathrm{a}=}-\Delta \mathrm{H} / \mathrm{RT}+\Delta \mathrm{S} / \mathrm{R}$

where $\mathrm{K}_{\mathrm{a}}$ is analogous to the associative binding constants at the corresponding temperature and $\mathrm{R}$ is the gas constant. The free energy change $(\Delta G)$ is then estimated from the following relationship (4):

$\Delta \mathrm{G}=\Delta \mathrm{H}-\mathrm{T} \Delta \mathrm{S}$
The negative sign obtained for $\Delta \mathrm{G}$ (Table 6 ) indicated a spontaneous interaction process. The negative enthalpy change suggested that the binding between the compounds and BSA was exothermic and then the association constant decrease with increasing temperature [54]. An important source of a negative contribution to $\Delta \mathrm{H}$ and $\Delta \mathrm{S}$ will arise if a hydrogen bond is formed and furthermore the interactions involving delocalized electrons of aromatic ring systems make significant contributions to their negative sign. The negative $\Delta H$ and $\Delta S$ values obtained for the interaction of baicalin and $\mathrm{V}^{\mathrm{IV}} \mathrm{O}$ (baic) with $\mathrm{BSA}$ indicated that the binding is mainly enthalpy driven with an unfavorable entropic factor and therefore the hydrogen bonding and van der Waals forces played major roles during the interactions [54].

\section{Conclusions}

As part of a project devoted to design new anti-cancer compounds with the natural antioxidant plant compounds, flavonoids and the oxidovanadium(IV) cation, we have synthesized and characterized a new solid complex with baicalin. In hot ethanolic solution at pH 9 a 1:2 metal-to-ligand solid complex has been obtained. Physicochemical determinations allowed the characterization of the solid complex. At such $\mathrm{pH}$ value the ligand is triple deprotonated leading to the formation of a bis-chelate compound with the oxidovanadium(IV) cation in which the coordination occurred through the phenoxy groups of ring A. By EPR spectroscopy it has been demonstrated that the equatorial environment was retained upon dissolution of the complex in DMSO. The antioxidant properties of baicalin are of medium intensity owing to the absence of hydroxyl groups on ring $\mathrm{B}$ and the $3-\mathrm{OH}$ group on ring $\mathrm{C}$. Oxidovanadium(IV) complexation enhanced the radical-scavenger activity for superoxide and peroxyl ROS. Even though and due to its
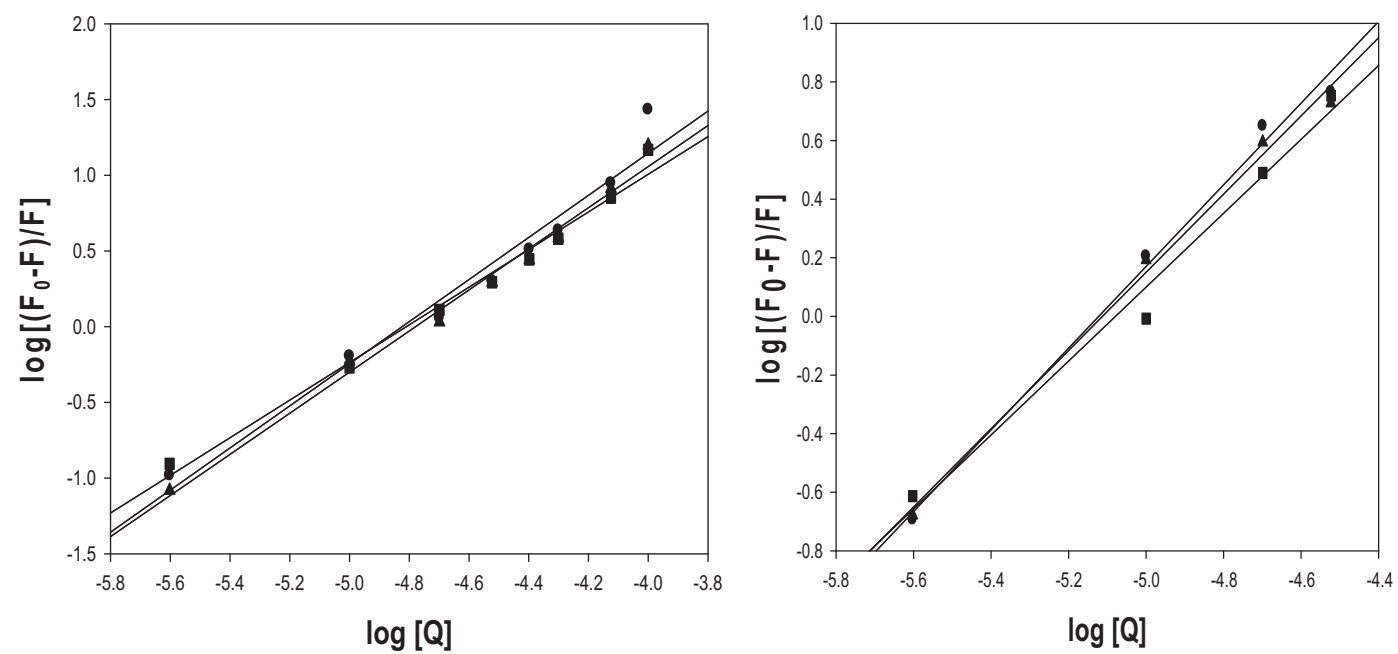

Fig. 13. Plots of $\log \left[\left(\mathrm{F}_{0}-\mathrm{F}\right) / \mathrm{F}\right]$ vs. $\log [\mathrm{Q}]$ for the baicalin-BSA system $(\mathrm{A})$ and $\mathrm{V}^{\mathrm{IV}} \mathrm{O}$ (baic)-BSA system (B):

$298 \mathrm{~K} ;(\mathbf{\Delta}), 303 \mathrm{~K}$;

$310 \mathrm{~K},[\mathrm{BSA}]=6 \mu \mathrm{M}, \lambda_{\mathrm{ex}}=280$ 


\section{Table 6}

Thermodynamic parameters for the interactions between baicalin and $\mathrm{V}^{\mathrm{IV}} \mathrm{O}$ (baic) with BSA.

\begin{tabular}{llll}
\hline Compounds & $\Delta \mathrm{H}(\mathrm{KJ} / \mathrm{mol})$ & $\Delta \mathrm{S}(\mathrm{J} / \mathrm{mol})$ & $\Delta \mathrm{G}(\mathrm{KJ} / \mathrm{mol})$ \\
\hline Baicalin & -104.40 & -221.14 & $-38.84(298 \mathrm{~K})$ \\
& & $-37.74(303 \mathrm{~K})$ \\
& & $-36.20(310 \mathrm{~K})$ \\
$\mathrm{V}^{\mathrm{IV}}$ O(baic) & -104.44 & -214.15 & $-40.62(298 \mathrm{~K})$ \\
& & $-39.98(303 \mathrm{~K})$ \\
& & $-38.05(310 \mathrm{~K})$ \\
\hline
\end{tabular}

structural characteristics the antioxidant capacity of the complex is moderate, the peroxyl scavenging power is one of the higher measured activities among a family of VOflavonid complexes studied. Using the brine shrimp test it can be determined that both baicalin and $\mathrm{V}^{\mathrm{IV}} \mathrm{O}$ (baic) did not display toxic effects and they did not exert mutagenic and therefore carcinogenic effects (Ames test). We found that baicalin slightly decreased the number of viable human lung cancer cells and that the coordination with oxidovanadium(IV) improved its action, especially noticeable at $72 \mathrm{~h}$ incubation times. A stress oxidative mechanism of action has been determined in concordance with the observations that when the generation of cellular ROS was suppressed the cell viability behaved like that of the untreated cells. Because of the decrease of the $\mathrm{K}_{\mathrm{sv}}$ values of baicalin and $\mathrm{V}^{\mathrm{IV}} \mathrm{O}$ (baic) with the temperature and the high $\mathrm{K}_{\mathrm{q}}$ values, greater than the maximum dynamic quenching constant, we can conclude that that a static quenching occurs during the interaction between the compounds and BSA at low concentrations. The thermodynamic parameters indicated that both compounds could be transported by the protein with spontaneous processes $(\Delta \mathrm{G}<0)$ and the presence of $\mathrm{H}$ bonding and van der Waals interactions $(\Delta \mathrm{H}<0$ and $\Delta \mathrm{S}<0$ ) between the protein and the added compounds.

\section{Abbreviations}

AAPH 2,2-azobis (2-amidinopropane) dihydrochloride

Baicalin (baic) (2S,3S,4S,5R,6S)-6-(5,6-dihydroxy-4-oxo-2-phenylchromen-7-yl)oxy-3,4,5-trihydroxy-tetrahydropyran-2-carboxylic acid

BSA Bovine serum albumin

DMEM Dulbecco's Modified Eagle's Medium

$\mathrm{DPPH}^{\bullet} \quad$ 1,1-Diphenyl-2-picrylhydrazyl

FBS Fetal bovine serum

H2DCFDA 2',7'-dichlorodihydrofluorescein diacetate

$\mathrm{LC}_{50} \quad$ Median lethal concentration

MI Mutagenic index

MTT 3-(4,5-dimethylthiazol-2-yl)-2,5diphenyltetrazolium bromide

NAC N-acetyl-L-cysteine

NBT Nitroblue tetrazolium

PBS Phosphate-buffered saline

PMS Phenazine methosulfate

ROS Reactive oxygen species

$\mathrm{V}^{\mathrm{IV}} \mathrm{O}$ (baic) $\left.\mathrm{Na}_{4}[\mathrm{VO} \text { (baic) })_{2}\right] \cdot 6 \mathrm{H}_{2} \mathrm{O}$

\section{Acknowledgements}

This work was supported by UNLP, CONICET, UNL, CICPBA (PICyT 813/13), PIP (2012-2014 GI) and ANPCyT (PICT 2013-0569, 20141742), Argentina. EGF, LGN are research fellows of CONICET. PAMW is a research fellow of CICPBA, Argentina. JJMM, ALP are fellowship holders from CONICET.

\section{Appendix A. Supplementary data}

Supplementary data to this article can be found online at http://dx. doi.org/10.1016/j.jinorgbio.2016.11.005.

\section{References}

[1] M.Y. Lai, S.L. Hsiu, S.Y. Tsai, Y.C. Hou, P.D. Lee Chao, J. Pharm. Pharmacol. 55 (2003) 205-209.

[2] A. Papaioannou, M. Manos, S. Karkabounas, R. Liasko, A.M. Evangelou, I Correia, V. Kalfakakou, J. Costa Pessoa, T. Kabanos, J. Inorg. Biochem. 98 (2004) 959-968.

[3] L.G. Naso, L. Lezama, M. Valcarcel, C. Salado, P. Villacé, D. Kortazar, E.G. Ferrer, P.A.M. Williams, J. Inorg. Biochem. 157 (2016) 80-93.

[4] E.G. Ferrer, M.V. Salinas, M.J. Correa, L. Naso, D.A. Barrio, S.B. Etcheverry, L. Lezama, T. Rojo, P.A.M. Williams, J. Biol. Inorg. Chem. 11 (2006) 791-801.

[5] L. Lewan, M. Andersson, P. Morales-Gomez, Altern. Lab. Anim 20 (1992) 297-301.

[6] M. Onishi, Photometric Determination of Traces of Metals, fourth ed. Wiley, NewYork, 1998 (part II).

[7] S. Stoll, A. Schweiger, J. Magn. Reson. 178 (2006) 42-55.

[8] B. Halliwell, J.M.C. Gutteridge, O. Aruoma, Anal. Biochem. 165 (1987) 215-219.

[9] W.Y. Huang, K. Majumder, J. Wu, Food Chem. 23 (2010) 635-641.

[10] C.D. Hapner, P. Deuster, Y. Chen, Chem. Biol. Interact. 186 (2010) 275-279.

[11] T. Yamaguchi, H. Takamura, T.C. Matoba, J. Terao, Biosci. Biotechnol. Biochem. 62 (1998) 1201-1204.

[12] W.O. Carter, P.K. Narayanan, J.P. Robinson, J. Leukoc. Biol. 55 (1994) 253-258.

[13] B.N. Meyer, N.R. Ferrigni, J.E. Putnam, L.B. Jacobsen, D.E. Nichols, J.L. McLaughlin, Planta Med. 45 (1982) 31-34.

[14] A. Bacchi, M. Carcelli, P. Pelagatti, C. Pelizzi, G. Pelizzi, F. Zani, J. Inorg. Biochem. 75 (1999) 123-133.

[15] D.M. Maron, B.N. Ames, Mutat. Res. 113 (1983) 173-215.

[16] A. Albert, E.P. Serjeant, The Determination of Ionization Constants. Chap. 9, Springer, Netherlands, 1984 136-175.

[17] J.H. Looker, W.W. Hanneman, J. Org. Chem. 27 (1962) 381-389.

[18] M. Guo, Z. Wu, C. Wang, X. Gao, Acta Pharm. Sin. 49 (2014) 337-345.

[19] Z. Li, J. Shi, Q Liu, X. He. Chinese Patent, PCT/CN2012/072601, 2013.

[20] N.D. Chasteen, Vanadyl (IV) Spin Probes, Inorganic and Biochemical Aspects, in: L.J. Berliner, J. Reuben (Eds.), Biological Magnetic Resonance, vol. 3, Plenum, New York, 1981.

[21] E. Garribba, E. Lodyga-Chruscinska, D. Sanna, G. Micera, Inorg. Chim. Acta 322 (2001) 87-98.

[22] D. Sanna, V. Ugone, G. Lubinu, G. Micera, E. Garribba, J. Inorg. Biochem. 140 (2014) $173-184$.

[23] R. Liang, R. Han, L.M. Fu, X.C. Ai, J.P. Zhang, L.H. Skibsted, J. Agric. Food Chem. 57 (2009) 7118-7124.

[24] E.G. Ferrer, P.A.M. Williams, E.J. Baran, J. Inorg. Biochem. 50 (1993) 253-262.

[25] S.B. Etcheverry, P.A.M. Williams, E.J. Baran, Carbohydr. Res. 302 (1997) 131.

[26] F. Cheng, Y. Lu, X. Zhong, W. Song, X. Wang, X. Sun, J. Qin, S. Guo, Q. Wang, Evid. Based Complement. Alternat. Med. 2013 (2013) 120261-120272.

[27] P. Liu, F. Han, B. Duan, T. Deng, X. Hou, M. Zhao, J. Food Sci. Technol. 50 (2013) 615-619.

[28] L. Naso, V.R. Martínez, L. Lezama, C. Salado, M. Valcarcel, E.G. Ferrer, P.A.M. Williams, Bioorg. Med. Chem. 24 (2016) 4108-4119.

[29] T. Kumagai, C.I. Muller, J.C. Desmond, Y. Imai, D. Heber, H.P. Koeffler, Leuk. Res. 31 (2007) 523-530.

[30] F.L. Chana, H.L. Choia, Z.Y. Chenb, P.S.F. Chanc, Y. Huang, Cancer Lett. 160 (2000) 219-228.

[31] S. Ikemoto, K. Sugimura, N. Yoshida, R. Yasumoto, S. Wada, K. Yamamoto, T. Kishimoto, Urology 55 (2000) 951-955.

[32] M.K. Nayak, A.S. Agrawal, S. Bose, S. Naskar, R. Bhowmick, S. Chakrabarti, S. Sarkar, M. Chawla-Sarkar, J. Antimicrob. Chemother. 69 (2014) 1298-1310.

[33] Y. Liu, X. He, X. Liu, H. Zuo, Z. Li, Z. Wu, C. Xiang, X. Lai, Zhongguo Zhong Yao Za Zhi 37 (2012) 1296-1302.

[34] H. Zhu, L. Han, X. Shi, B. Wang, H. Huang, X. Wang, D. Chen, D. Ju, M. Feng, Antivir Res. 113 (2015) 62-70.

[35] K. Sak, Pharmacogn. Rev. 8 (2014) 122-146.

[36] J. Gao, W.A. Morgan, A. Sanchez-Medina, O. Corcoran, Toxicol. Appl. Pharmacol. 254 (2011) 221-228.

[37] T. Coimbra Diniz, J. Cabral Silva, S.R. Gomes de Lima-Saraiva, F. Pires Rodrigues de Almeida Ribeiro, A. Gomes Marques Pacheco, R. Mendes de Freitas, L.J. QuintansJúnior, J. de Souza Siqueira Quintans, R.L. Mendes, J.R. Guedes da Silva Almeida, Oxidative Med. Cell. Longev. 2015 (2015) 1-9.

[38] A.A. Mahdi, Free Radicals and Other Antioxidants, in: S.P. Singh (Ed.), A Textbook of Biochemistry, third ed.CBS, New Delhi 2002, pp. 545-555.

[39] K.M. Janisch, J. Milde, H. Schempp, E.F. Elstner, Vitamin C, vitamin E and flavonoids, Basic Clin. Res. 38 (2005) 59-69.

[40] W. Chen, T. Kuo, Y. Tzeng, Y. Tsai, Molecules 17 (2012) 3844-3857.

[41] H. Lu, S. Hsueh, Y. Ho, M. Kao, J. Yang, T. Chiu, S. Huamg, C. Lin, J. Chung, Anticancer Res. 27 (2007) 117-126.

[42] Z. Ren, H. Yu, J. Li, J. Shen, W. Du, Biosci. Rep. 35 (e00202) (2015) 1-7.

[43] G.M. Molina-Salinas, S. Said-Fernández, Pharmacologyonline 3 (2006) 633-638.

[44] A. Lagarto Parra, R. Silva Yhebra, I. Guerra Sardiñas, L. Iglesias Buela, Phytomedicine 8 (2001) 395-400.

[45] M.S. Islas, L.G. Naso, L. Lezama, M. Valcarcel, C. Salado, M. Roura-Ferrer, E.G. Ferrer, P.A.M. Williams, J. Inorg. Biochem. 149 (2015) 12-24.

[46] Y. Moriyama, D. Ohta, K. Hachiya, Y. Mitsui, K. Takeda, J. Protein Chem. 15 (1996) 265-272.

[47] R. Itri, W. Caetano, L.R.S. Barbosa, M.S. Baptista, Braz. J. Phys. 34 (2004) 58-63.

[48] E. Liu, L. Qi, P. Li, Molecules 15 (2010) 9092-9103. 
[49] J.R. Lakowicz (Ed.), Principles of Fluorescence Spectroscopy, Springer Science \& Business Media, New York, USA, 2013.

[50] X. Shi, X. Li, M. Gui, H. Zhou, R. Yang, H. Zhang, Y. Jin, J. Lumin. 130 (2010) 637-644.

51] J.B. Xiao, J.W. Chen, H. Cao, F.L. Rena, C.S. Yang, Y. Chen, M. Xud, J. Photochem, Photobiol. A Chem. 191 (2007) 222-227.
[52] Q. Xu, D. Deng, Z. Cao, Q. Xie, J. Liang, J. Lu, Chin. J. Anal. Chem. 38 (2010) 483-487.

[53] J. Shi, H. Cao, Braz. J. Pharmacogn. 21 (2011) 594-600.

[54] P.D. Ross, S. Subramanian, Biochemistry 20 (1981) 3096-3102. 